Supporting Information

\title{
Haliclonadiamine Derivatives and 6-epi-Monanchorin from the Marine Sponge Halichondria panicea Collected at Iriomote Island
}

Delfly B. Abdjul, ${ }^{\dagger \dagger}$ Hiroyuki Yamazaki, ${ }^{* \dagger}$ Syu-ichi Kanno, ${ }^{\dagger}$ Ohgi Takahashi, ${ }^{\dagger}$ Ryota Kirikoshi, ${ }^{\dagger}$ Kazuyo Ukai, ${ }^{\dagger}$ and Michio Namikoshi ${ }^{\dagger}$

${ }^{\dagger}$ Faculty of Pharmaceutical Sciences, Tohoku Medical and Pharmaceutical University, Sendai 981-8558, Japan.

${ }^{\dagger}$ Faculty of Fisheries and Marine Science, Sam Ratulangi University, Kampus Bahu, Manado 95115, Indonesia.

\section{Contents}

Spectroscopic data for compounds $\mathbf{5 , 6}$, and $\mathbf{8}$.

Figure S1. ${ }^{1} \mathrm{H}$ NMR spectrum of $\mathbf{1}$ in $\mathrm{CD}_{3} \mathrm{OD}$.

Figure S2. ${ }^{13} \mathrm{C}$ NMR spectrum of $\mathbf{1}$ in $\mathrm{CD}_{3} \mathrm{OD}$.

Figure S3. DEPT spectrum of $\mathbf{1}$ in $\mathrm{CD}_{3} \mathrm{OD}$.

Figure S4. ${ }^{1} \mathrm{H}-{ }^{1} \mathrm{H}$ COSY spectrum of $\mathbf{1}$ in $\mathrm{CD}_{3} \mathrm{OD}$.

Figure S5. HMQC spectrum of $\mathbf{1}$ in $\mathrm{CD}_{3} \mathrm{OD}$.

Figure S6. $\mathrm{HMBC}$ spectrum of $\mathbf{1}$ in $\mathrm{CD}_{3} \mathrm{OD}$.

Figure S7. NOESY spectrum of $\mathbf{1}$ in $\mathrm{CD}_{3} \mathrm{OD}$.

Figure S8. ${ }^{1} \mathrm{H}$ NMR spectrum of 2 in $\mathrm{CD}_{3} \mathrm{OD}$.

Figure S9. ${ }^{13} \mathrm{C}$ NMR spectrum of 2 in $\mathrm{CD}_{3} \mathrm{OD}$.

Figure S10. DEPT spectrum of 2 in $\mathrm{CD}_{3} \mathrm{OD}$.

Figure S11. ${ }^{1} \mathrm{H}-{ }^{1} \mathrm{H}$ COSY spectrum of 2 in $\mathrm{CD}_{3} \mathrm{OD}$.

Figure S12. HMQC spectrum of 2 in $\mathrm{CD}_{3} \mathrm{OD}$.

Figure S13. $\mathrm{HMBC}$ spectrum of 2 in $\mathrm{CD}_{3} \mathrm{OD}$.

Figure S14. NOESY spectrum of 2 in $\mathrm{CD}_{3} \mathrm{OD}$. 
Figure S15. ${ }^{1} \mathrm{H}$ NMR spectrum of 3 in $\mathrm{CD}_{3} \mathrm{OD}$.

Figure S16. ${ }^{13} \mathrm{C}$ NMR spectrum of $\mathbf{3}$ in $\mathrm{CD}_{3} \mathrm{OD}$.

Figure S17. DEPT spectrum of 3 in $\mathrm{CD}_{3} \mathrm{OD}$.

Figure S18. ${ }^{1} \mathrm{H}-{ }^{1} \mathrm{H}$ COSY spectrum of 3 in $\mathrm{CD}_{3} \mathrm{OD}$.

Figure S19. HMQC spectrum of $\mathbf{3}$ in $\mathrm{CD}_{3} \mathrm{OD}$.

Figure S20. $\mathrm{HMBC}$ spectrum of $\mathbf{3}$ in $\mathrm{CD}_{3} \mathrm{OD}$.

Figure S21. NOESY spectrum of $\mathbf{3}$ in $\mathrm{CD}_{3} \mathrm{OD}$.

Figure S22. ${ }^{1} \mathrm{H}$ NMR spectrum of 4 in $\mathrm{CD}_{3} \mathrm{OD}$.

Figure S23. ${ }^{13} \mathrm{C}$ NMR spectrum of 4 in $\mathrm{CD}_{3} \mathrm{OD}$.

Figure S24. DEPT spectrum of 4 in $\mathrm{CD}_{3} \mathrm{OD}$.

Figure S25. ${ }^{1} \mathrm{H}-{ }^{1} \mathrm{H}$ COSY spectrum of 4 in $\mathrm{CD}_{3} \mathrm{OD}$.

Figure S26. HMQC spectrum of 4 in $\mathrm{CD}_{3} \mathrm{OD}$.

Figure S27. $\mathrm{HMBC}$ spectrum of $\mathbf{4}$ in $\mathrm{CD}_{3} \mathrm{OD}$.

Figure S38. NOESY spectrum of 4 in $\mathrm{CD}_{3} \mathrm{OD}$.

Figure S29. ${ }^{1} \mathrm{H}$ NMR spectrum of 7 in DMSO- $d_{6}$.

Figure S30. ${ }^{13} \mathrm{C}$ NMR spectrum of 7 in DMSO- $d_{6}$.

Figure S31. DEPT spectrum of 7 in DMSO- $d_{6}$.

Figure S32. ${ }^{1} \mathrm{H}-{ }^{1} \mathrm{H}$ COSY spectrum of 7 in DMSO- $d_{6}$.

Figure S33. HMQC spectrum of 7 in DMSO- $d_{6}$.

Figure S34. HMBC spectrum of 7 in DMSO- $d_{6}$.

Figure S35. NOESY spectrum of 7 in DMSO- $d_{6}$. 
Haliclonadiamine (5): Yellow oil; UV $\left(\mathrm{CH}_{3} \mathrm{OH}\right) \lambda_{\max }(\log \varepsilon) 241$ (4.3) nm; ${ }^{1} \mathrm{H} \mathrm{NMR}$ $\left(\mathrm{CD}_{3} \mathrm{OD}\right) \delta 6.39(1 \mathrm{H}, \mathrm{dd}, J=14.4,10.2 \mathrm{~Hz}, \mathrm{H}-12), 6.35(1 \mathrm{H}, \mathrm{dd}, J=14.4,10.2 \mathrm{~Hz}$, H-11), $5.61(1 \mathrm{H}, \mathrm{dd}, J=14.4,10.4 \mathrm{~Hz}, \mathrm{H}-10), 5.54(1 \mathrm{H}, \mathrm{dd}, J=14.4,9.8 \mathrm{~Hz}, \mathrm{H}-13)$, 3.58 (1H, m, H-22), 3.57 (1H, m, H-20), 3.29 (1H, m, H-1), 3.25 (1H, m, H-26b), 2.94 (1H, ddd, $J=12.3,12.3,5.3 \mathrm{~Hz}, \mathrm{H}-24 \mathrm{~b}), 2.66$ (1H, m, H-24a), 2.59 (1H, m, H-26a), $2.56(1 \mathrm{H}, \mathrm{m}, \mathrm{H}-14), 2.34$ (1H, brq, $J=10.4 \mathrm{~Hz}, \mathrm{H}-9), 2.17$ (1H, m, H-21b), 2.01 (1H, m, H-25b), 1.83 (1H, m, H-25a), 1.81 (2H, m, H-2), 1.45 (1H, m, H-3), 1.16 (2H, m, H-15, H-21a), 1.08 (1H, m, H-8), 1.03-1.83 (16H, m, H-4, H-5, H-6, H-7, H-16, H-17, H-18, $\mathrm{H}-19) ;{ }^{13} \mathrm{C} \mathrm{NMR}\left(\mathrm{CD}_{3} \mathrm{OD}\right) \delta 137.1,136.7,132.3,131.7,67.9,63.4,57.0,52.7,50.6$, $49.3,47.3,46.2,45.4,44.6,38.3,34.5,32.4,31.9,30.8,30.3,27.3,27.1,26.9,26.8$, 25.1; EIMS $m / z 368[\mathrm{M}]^{+}$.

Papuamine (6): Yellow oil; UV $\left(\mathrm{CH}_{3} \mathrm{OH}\right) \lambda_{\max }(\log \varepsilon) 240(4.2) \mathrm{nm} ;{ }^{1} \mathrm{H} \mathrm{NMR}\left(\mathrm{CD}_{3} \mathrm{OD}\right)$ $\delta 6.38$ (2H, m, H-11, H-12), 5.71 (2H, m, H-10, H-13), 3.50 (2H, dd, J = 16.6, 7.8 Hz, H-1, H-22), 3.05 (2H, m, H-24b, H-26b), 2.95 (2H, m, H-24a, H-26a), 2.54 (2H, dd, J= 19.8, 9.0 Hz, H-9, H-14), 2.33 (4H, m, H-2, H-21), 1.86 (2H, m, H-25), 1.24 (2H, m, H-8, H-15), 1.18 (2H, m, H-3, H-20), 1.0-1.9 (16H, m, H-4, H-5, H-6, H-7, H-16, H-17, $\mathrm{H}-18, \mathrm{H}-19) ;{ }^{13} \mathrm{C}$ NMR $\left(\mathrm{CD}_{3} \mathrm{OD}\right) \delta 136.1,130.4,62.1,50.5,49.3,46.6,44.6,39.0,32.1$, 30.8, 27.0, 24.4; EIMS $m / z 368[\mathrm{M}]^{+}$.

Monanchorin (8): Yellow oil; UV $\left(\mathrm{CH}_{3} \mathrm{OH}\right) \lambda_{\max }(\log \varepsilon) 201(3.8) \mathrm{nm} ;{ }^{1} \mathrm{H}$ and ${ }^{13} \mathrm{C} \mathrm{NMR}$ (DMSO- $d_{6}$ ), Table 3; EIMS m/z $211[\mathrm{M}]^{+}$. 


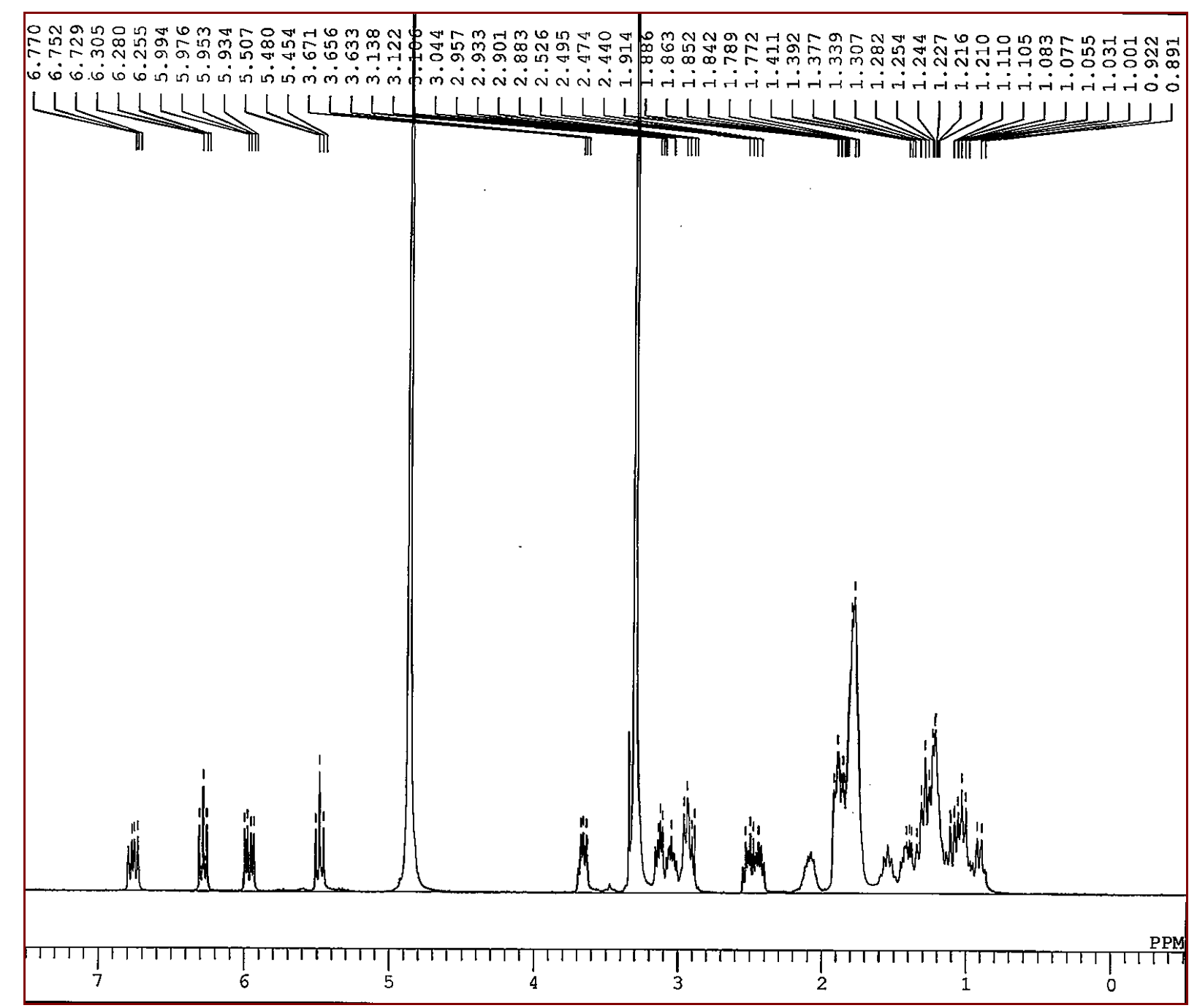

Figure S1. ${ }^{1} \mathrm{H}$ NMR spectrum of $\mathbf{1}$ in $\mathrm{CD}_{3} \mathrm{OD}$. 


$$
\pm
$$




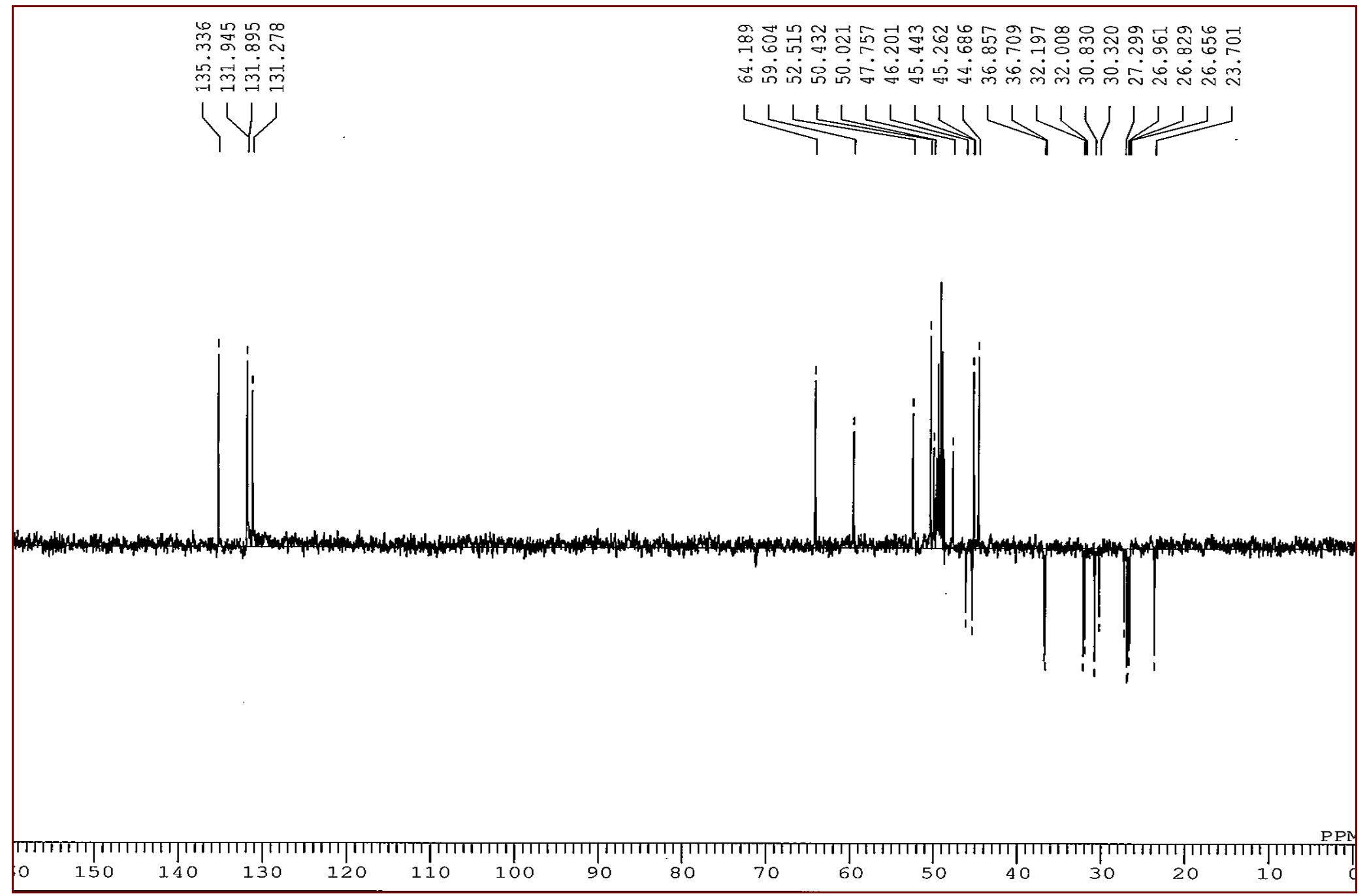

Figure S3. DEPT spectrum of $\mathbf{1}$ in $\mathrm{CD}_{3} \mathrm{OD}$. 


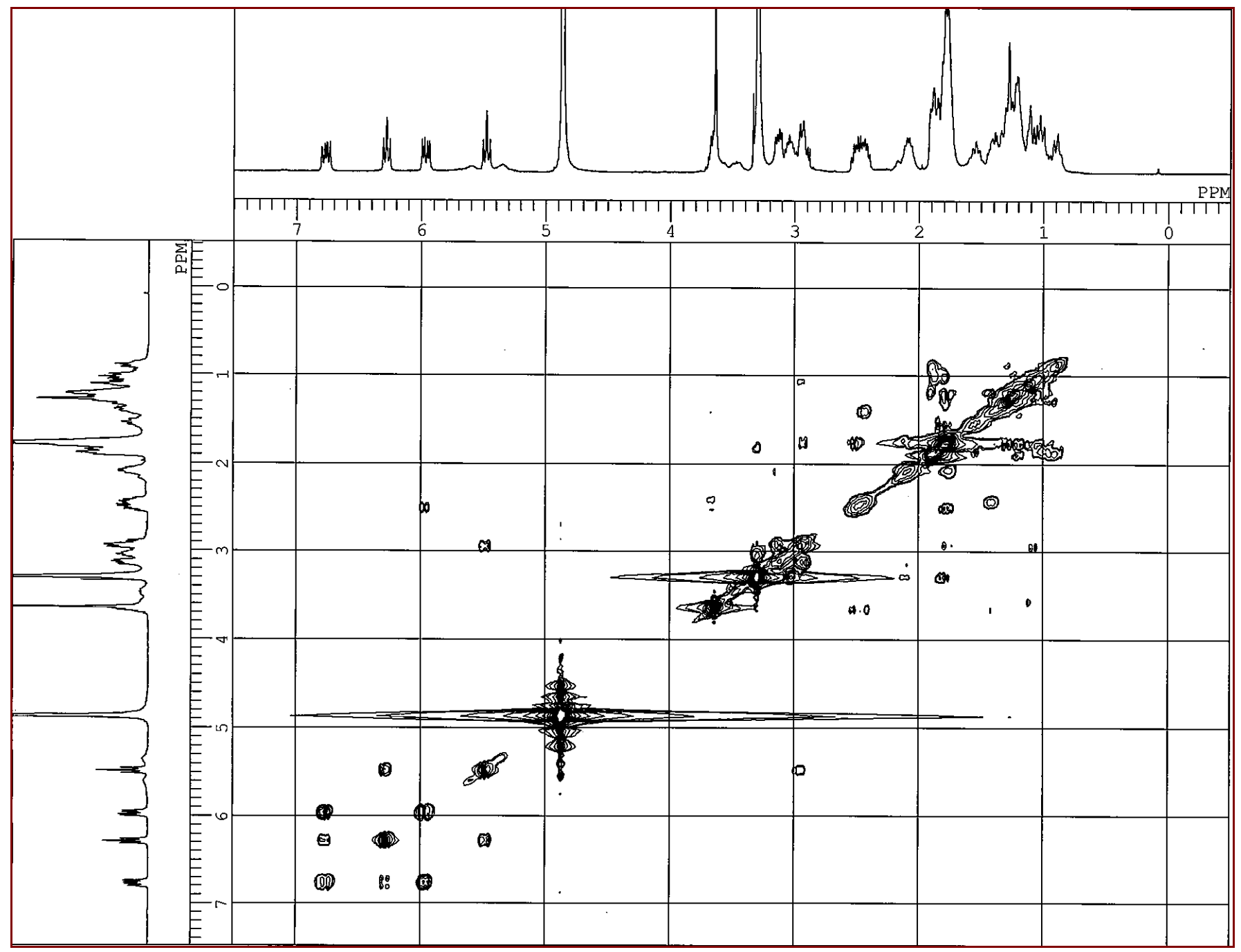

Figure S4. ${ }^{1} \mathrm{H}-{ }^{1} \mathrm{H}$ COSY spectrum of $\mathbf{1}$ in $\mathrm{CD}_{3} \mathrm{OD}$. 


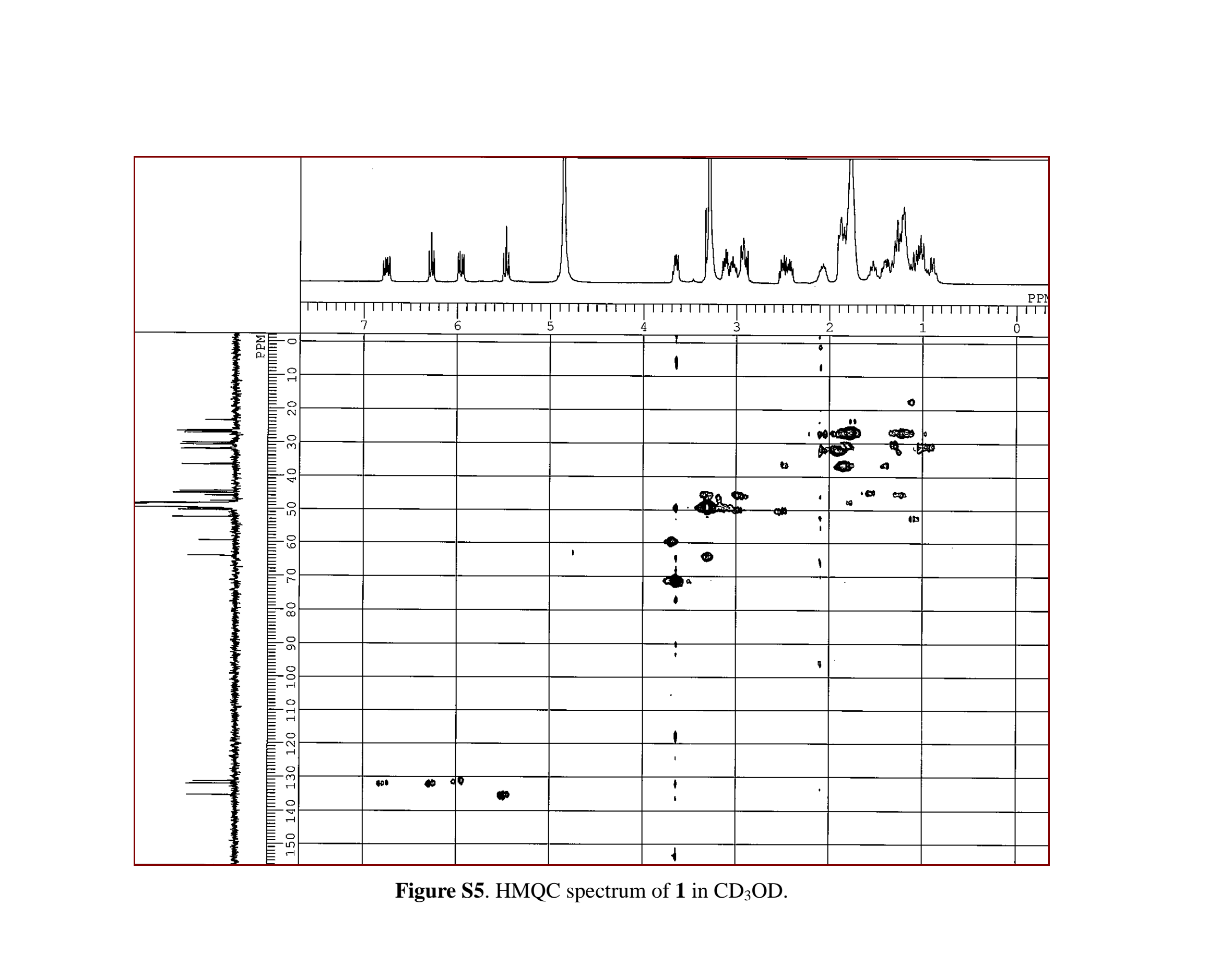




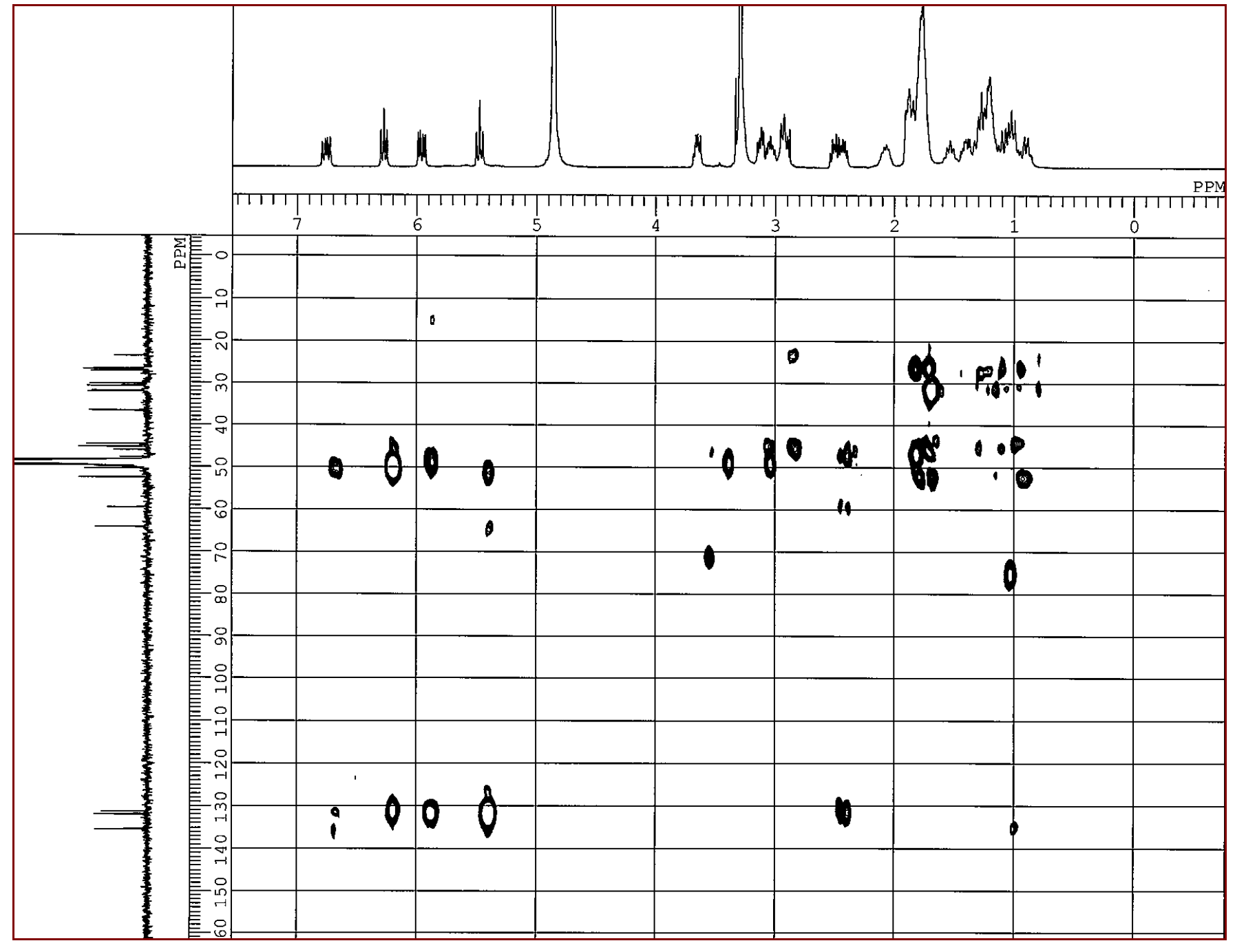

Figure S6. $\mathrm{HMBC}$ spectrum of $\mathbf{1}$ in $\mathrm{CD}_{3} \mathrm{OD}$. 


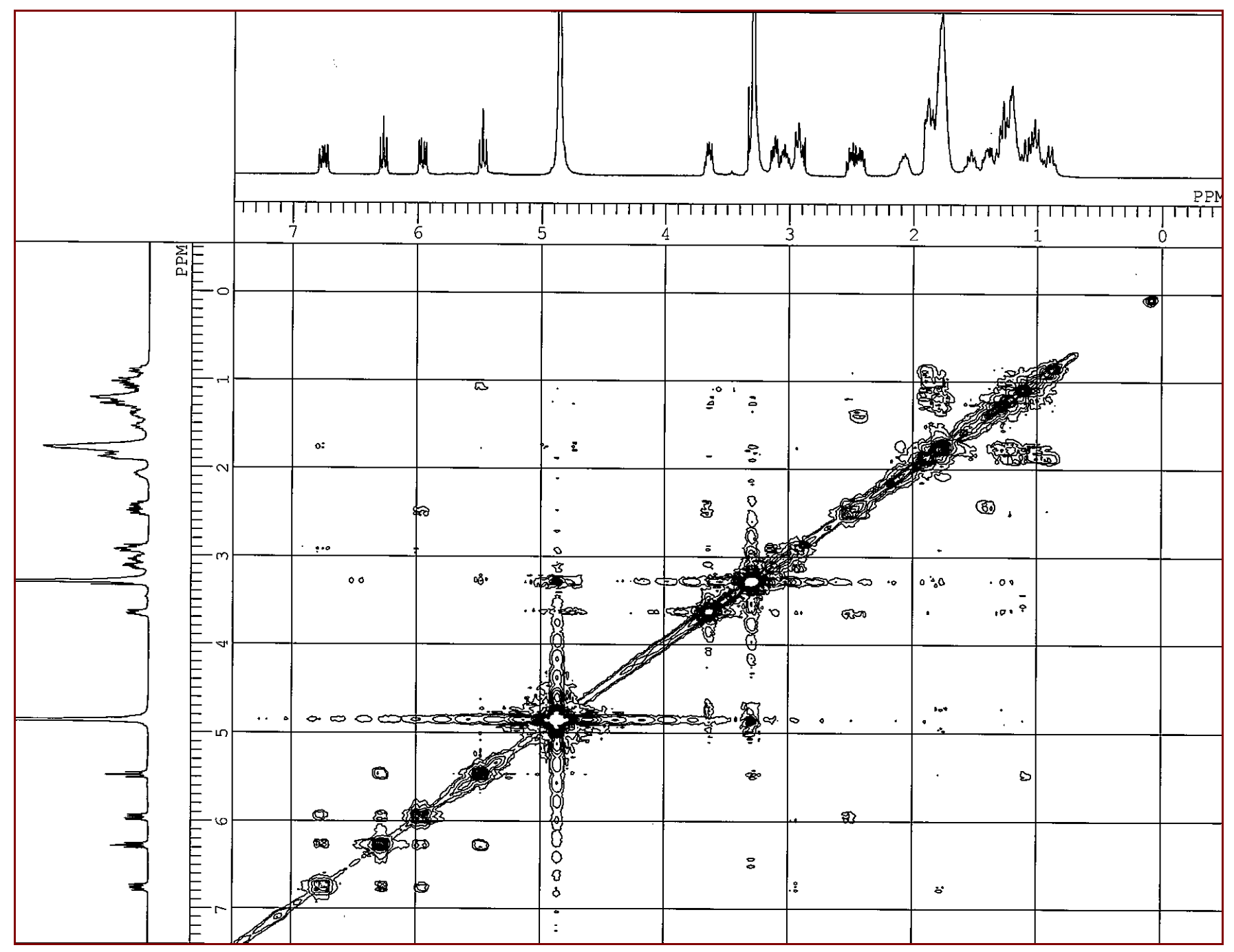

Figure S7. NOESY spectrum of $\mathbf{1}$ in $\mathrm{CD}_{3} \mathrm{OD}$. 


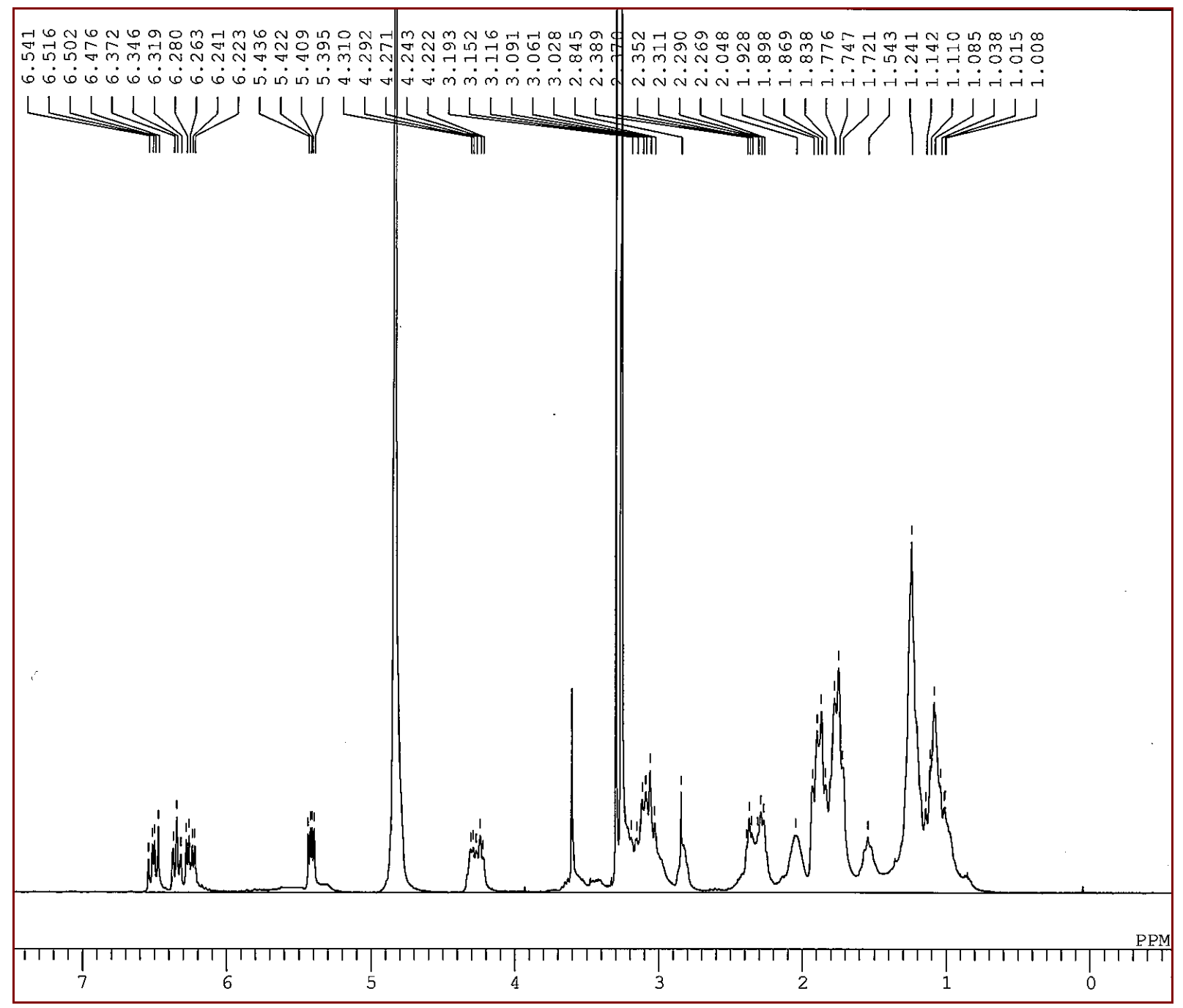

Figure $\mathbf{S 8}{ }^{1} \mathrm{H}$ NMR spectrum of $\mathbf{2}$ in $\mathrm{CD}_{3} \mathrm{OD}$. 


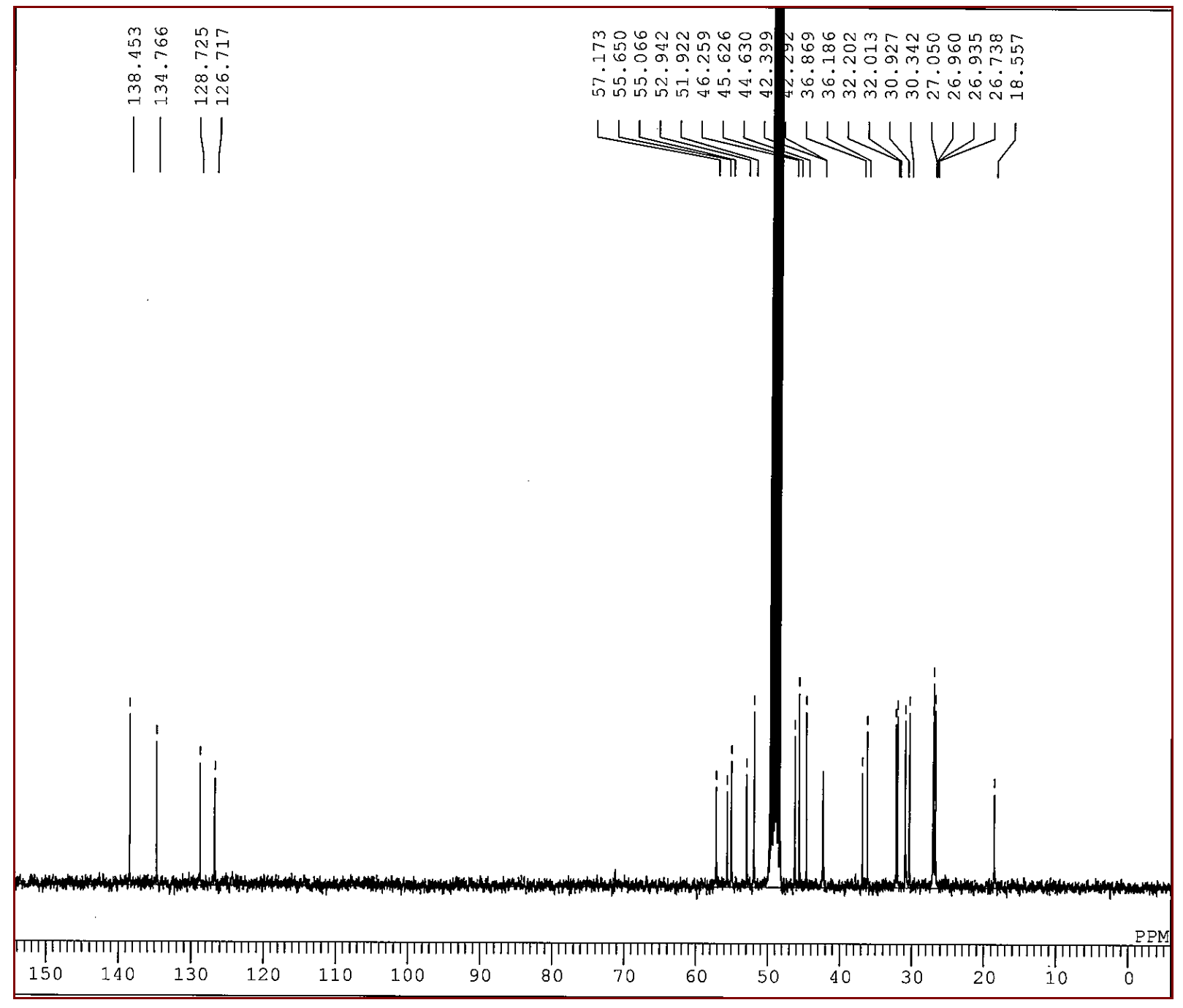

Figure S9. ${ }^{13} \mathrm{C}$ NMR spectrum of $\mathbf{2}$ in $\mathrm{CD}_{3} \mathrm{OD}$. 


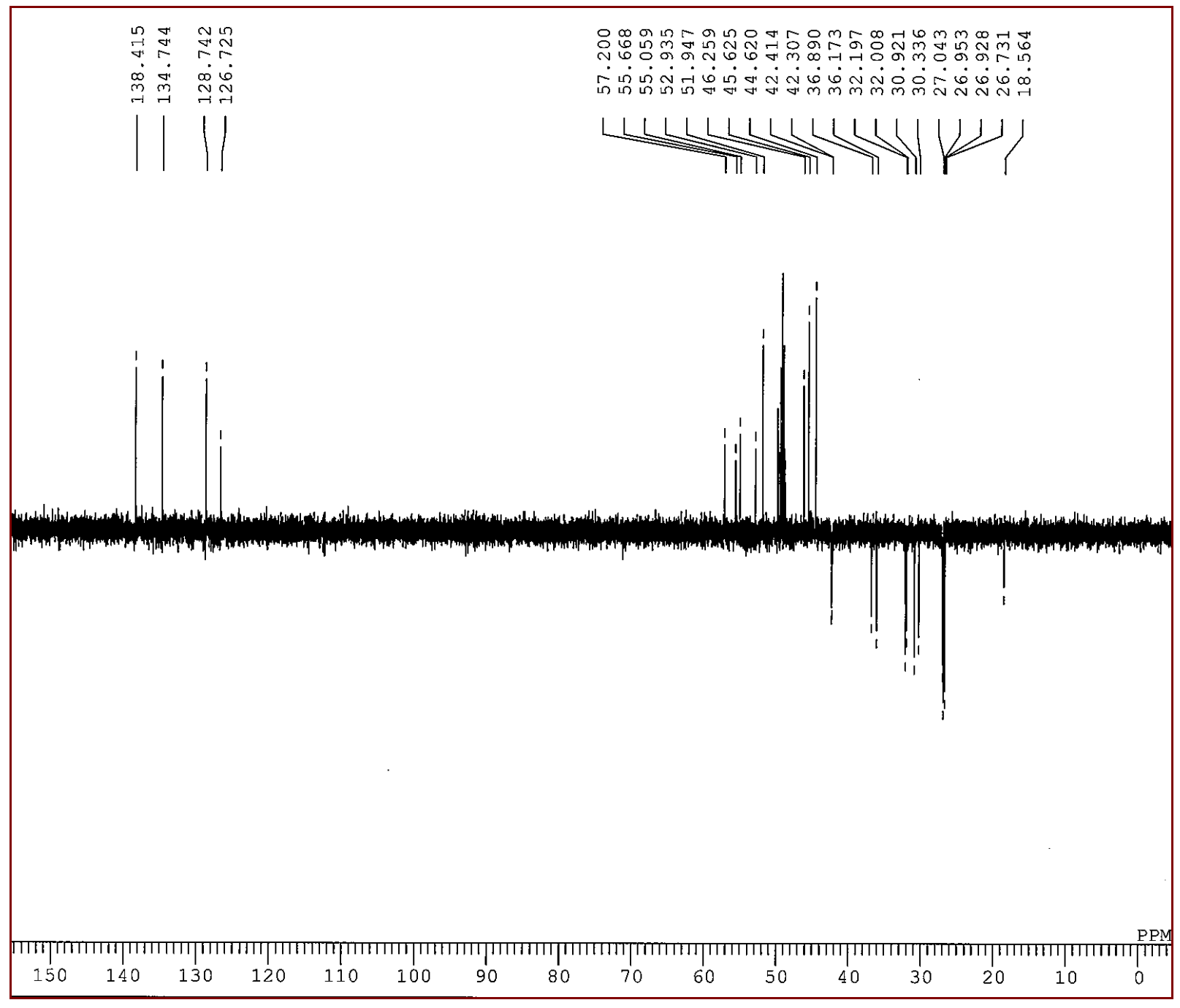

Figure S10. DEPT spectrum of 2 in $\mathrm{CD}_{3} \mathrm{OD}$. 


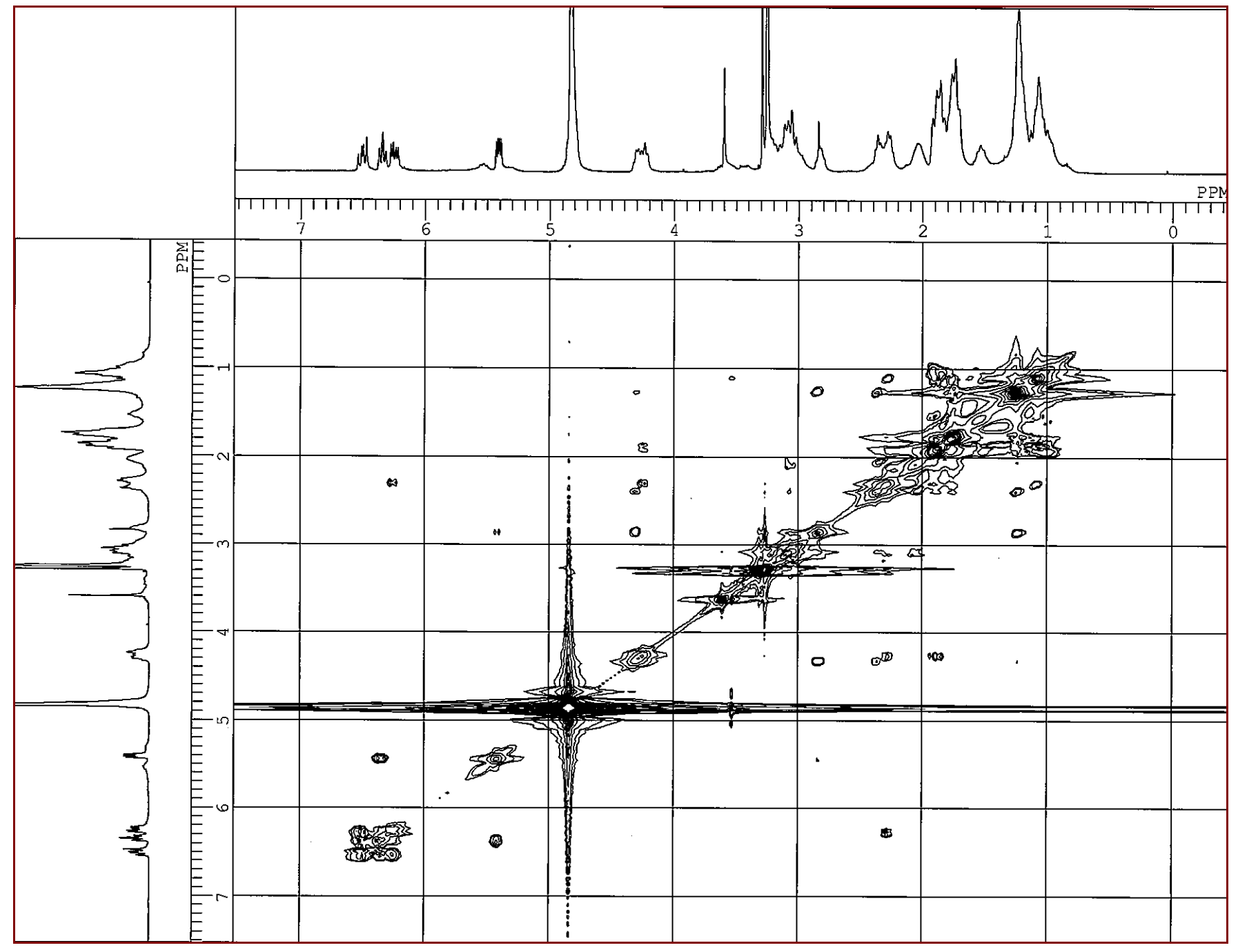

Figure S11. ${ }^{1} \mathrm{H}-{ }^{1} \mathrm{H}$ COSY spectrum of 2 in $\mathrm{CD}_{3} \mathrm{OD}$. 


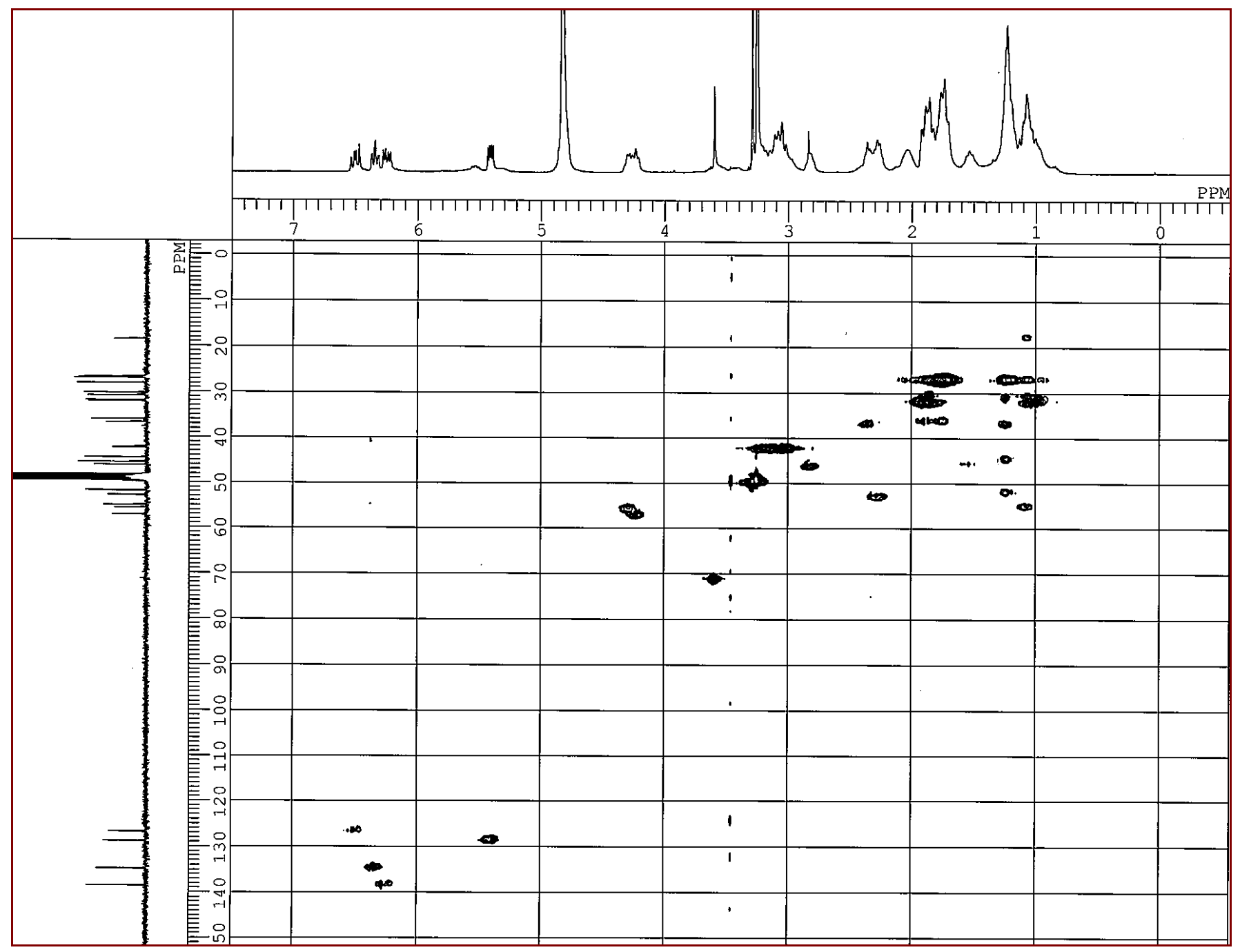

Figure S12. $\mathrm{HMQC}$ spectrum of $\mathbf{2}$ in $\mathrm{CD}_{3} \mathrm{OD}$. 


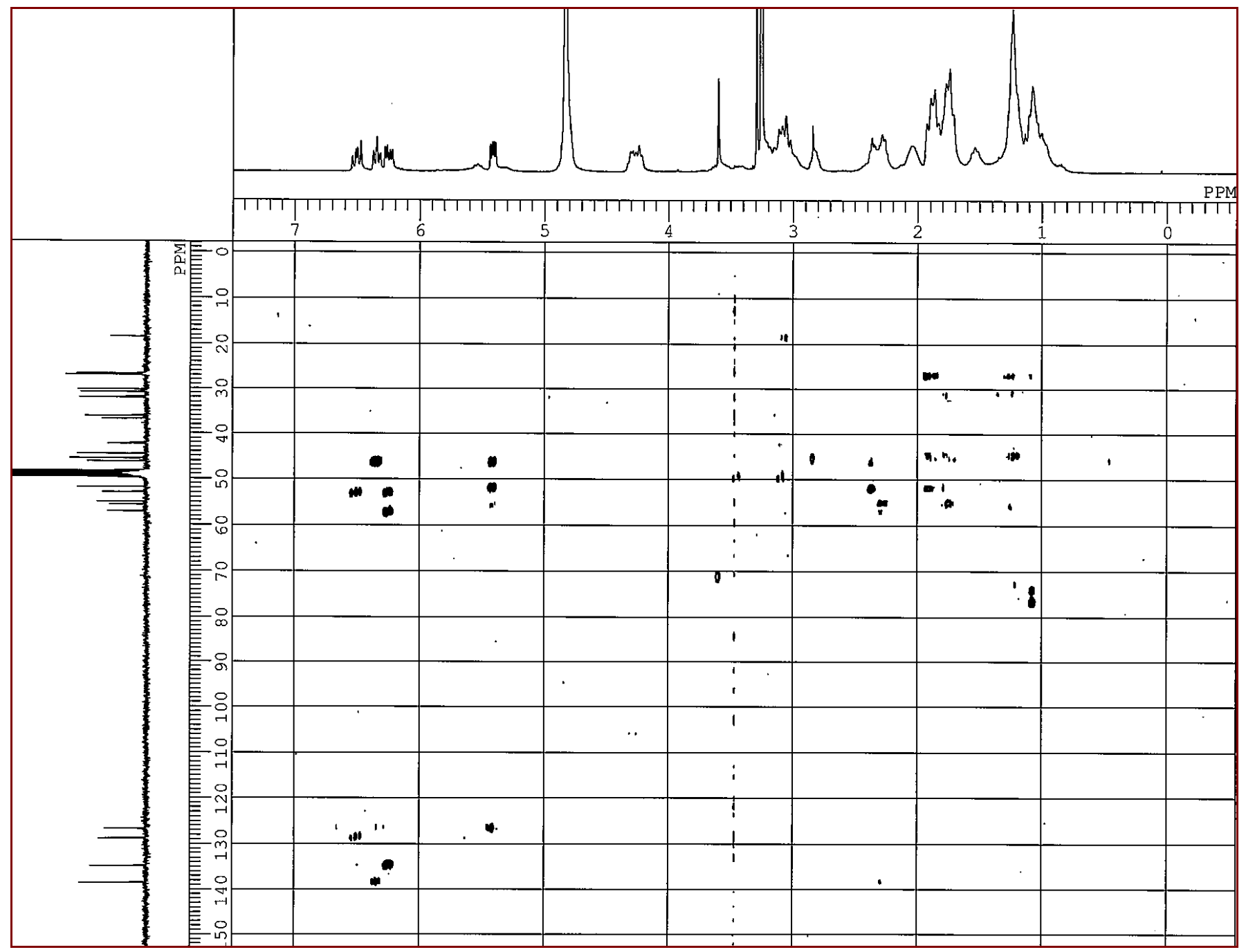

Figure S13. $\mathrm{HMBC}$ spectrum of 2 in $\mathrm{CD}_{3} \mathrm{OD}$. 


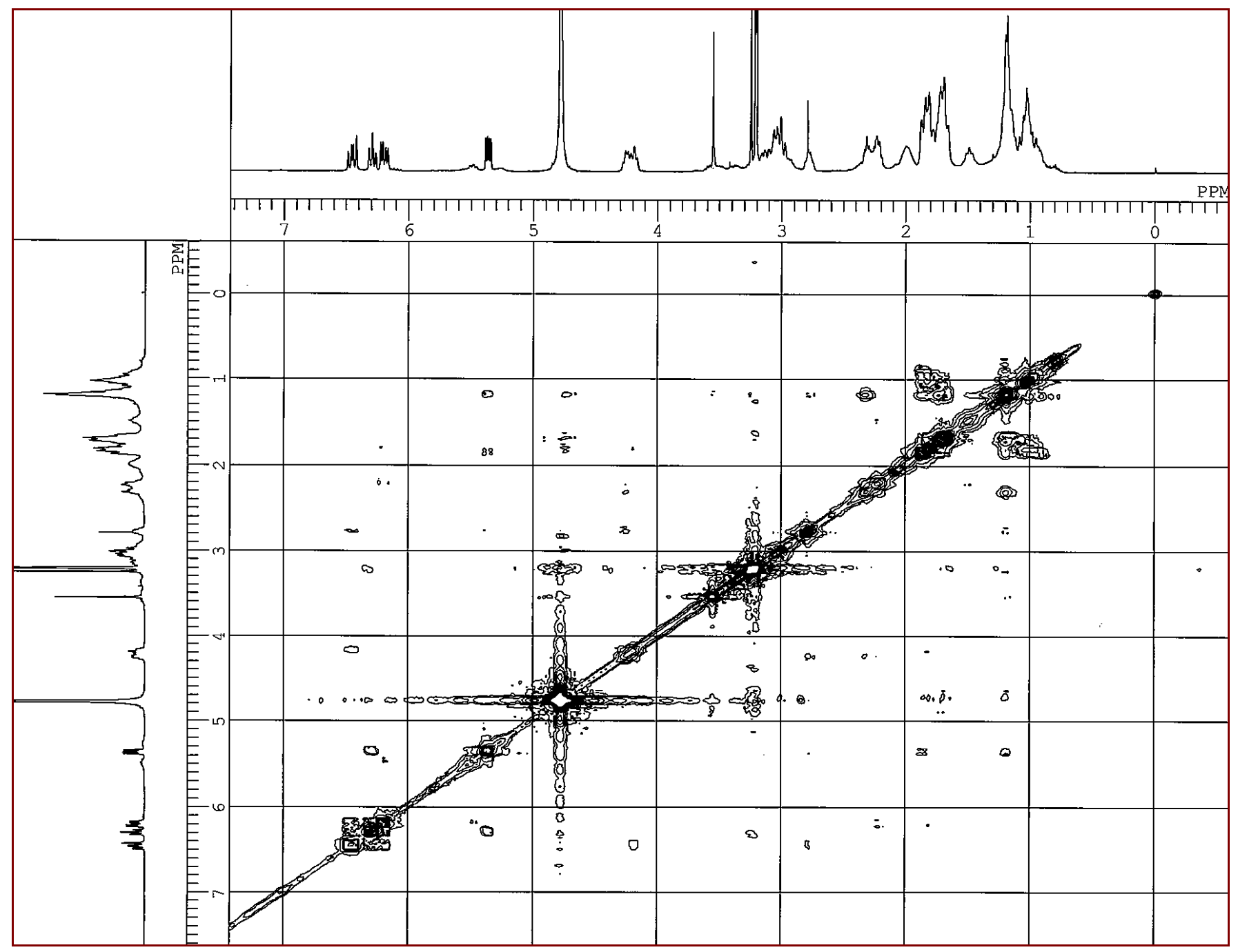

Figure S14. NOESY spectrum of $\mathbf{2}$ in $\mathrm{CD}_{3} \mathrm{OD}$. 


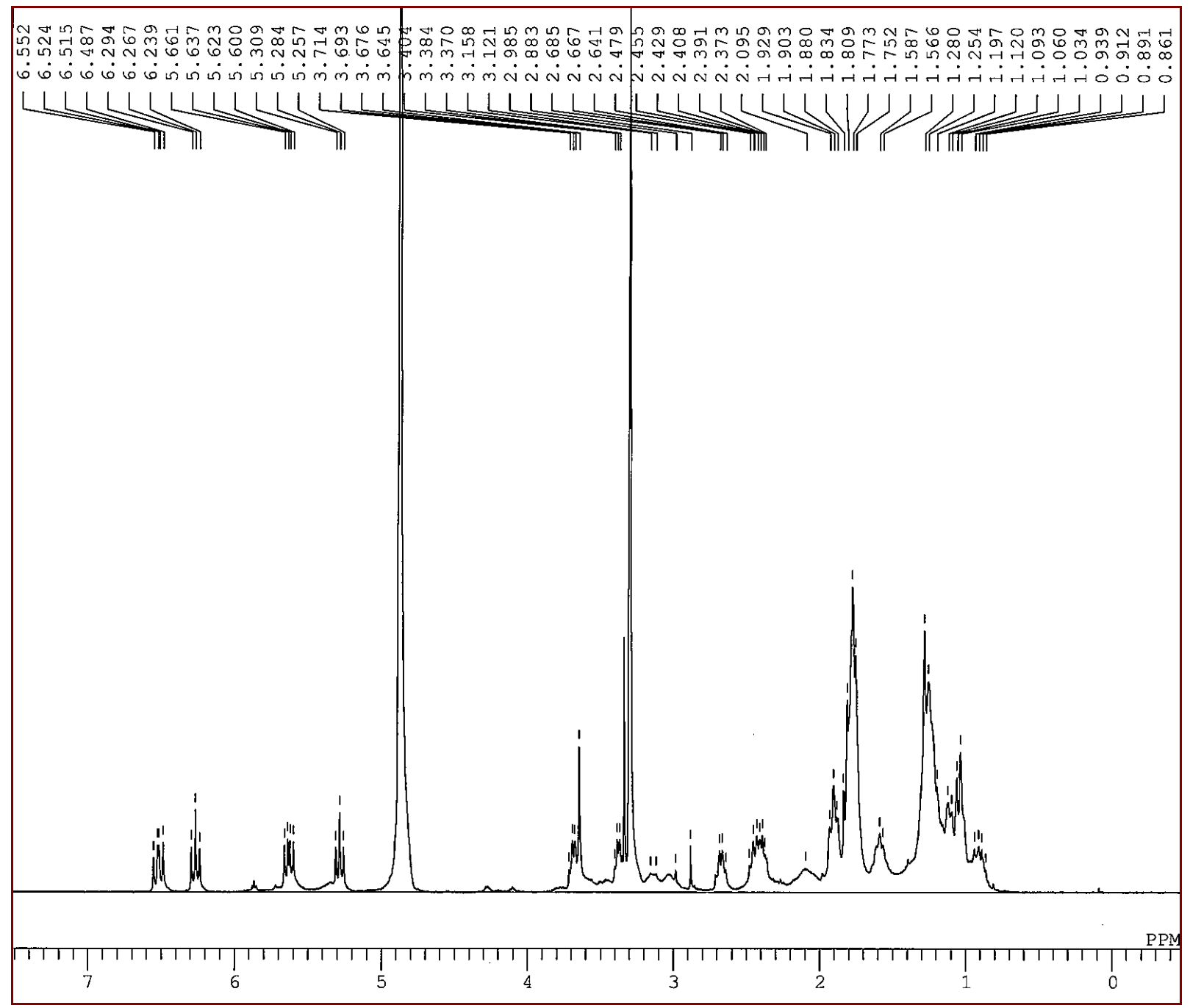

Figure S15. ${ }^{1} \mathrm{H}$ NMR spectrum of $\mathbf{3}$ in $\mathrm{CD}_{3} \mathrm{OD}$. 


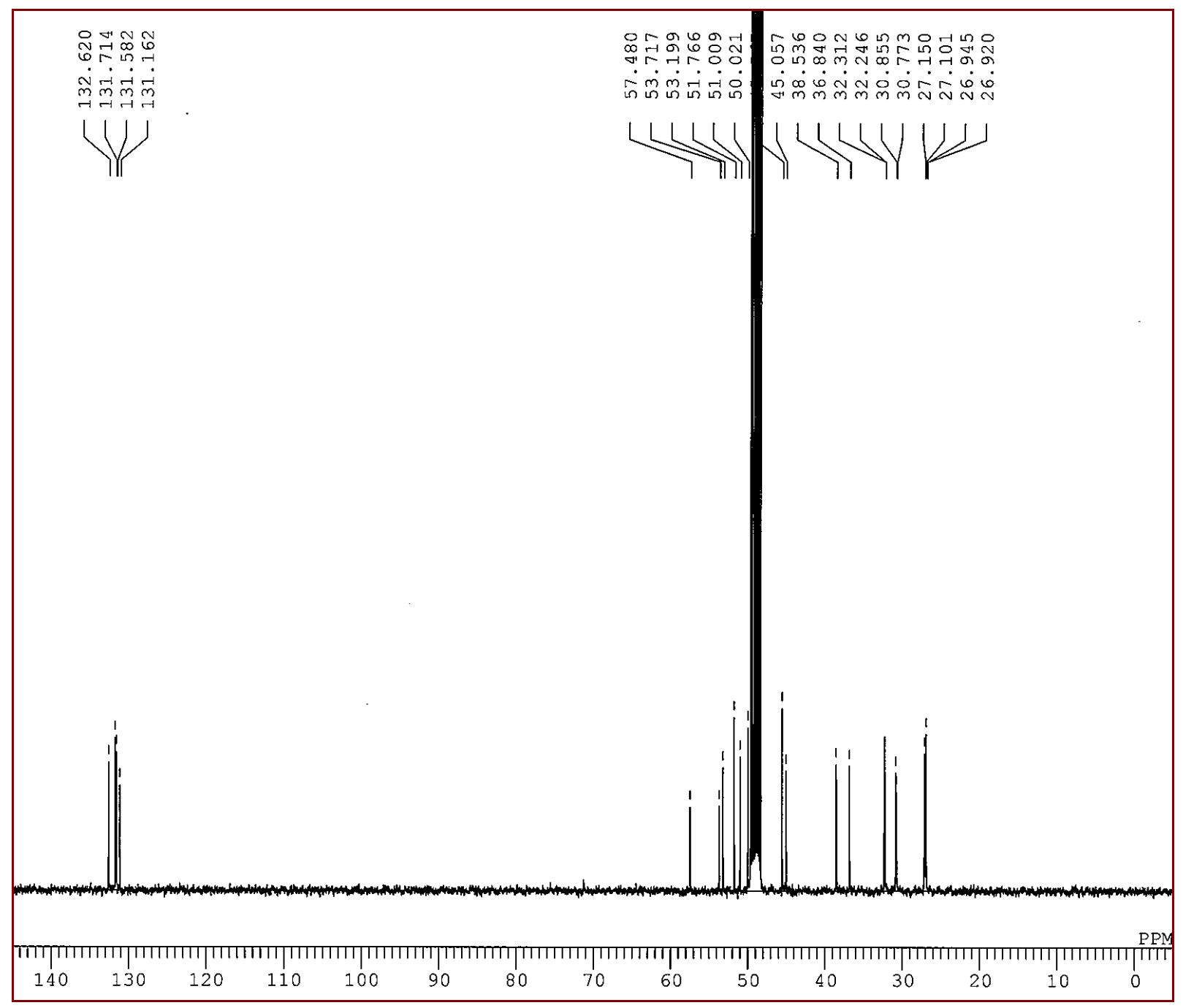

Figure S16. ${ }^{13} \mathrm{C}$ NMR spectrum of $\mathbf{3}$ in $\mathrm{CD}_{3} \mathrm{OD}$. 


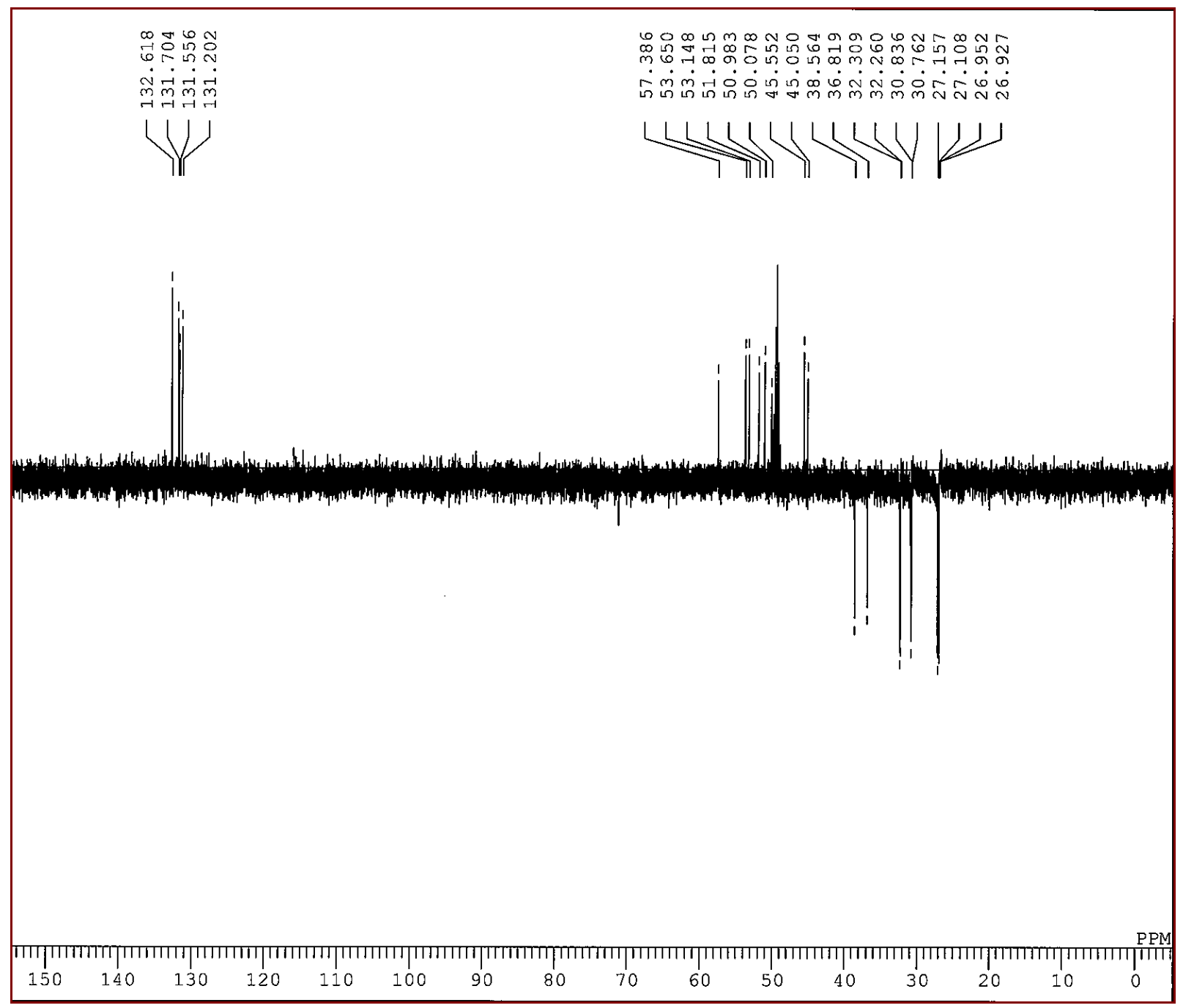

Figure S17. DEPT spectrum of $\mathbf{3}$ in $\mathrm{CD}_{3} \mathrm{OD}$. 


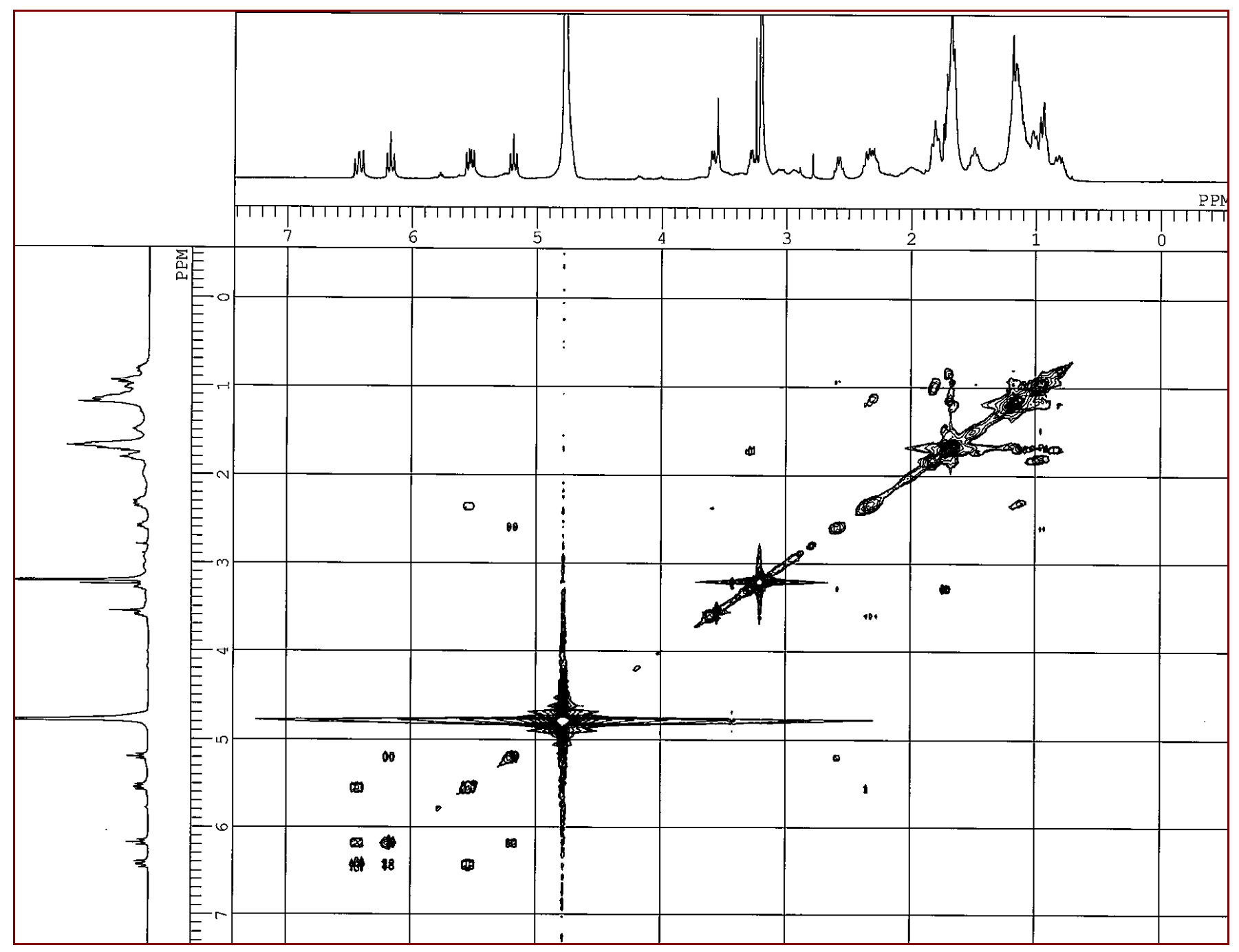

Figure S18. ${ }^{1} \mathrm{H}-{ }^{1} \mathrm{H}$ COSY spectrum of 3 in $\mathrm{CD}_{3} \mathrm{OD}$. 


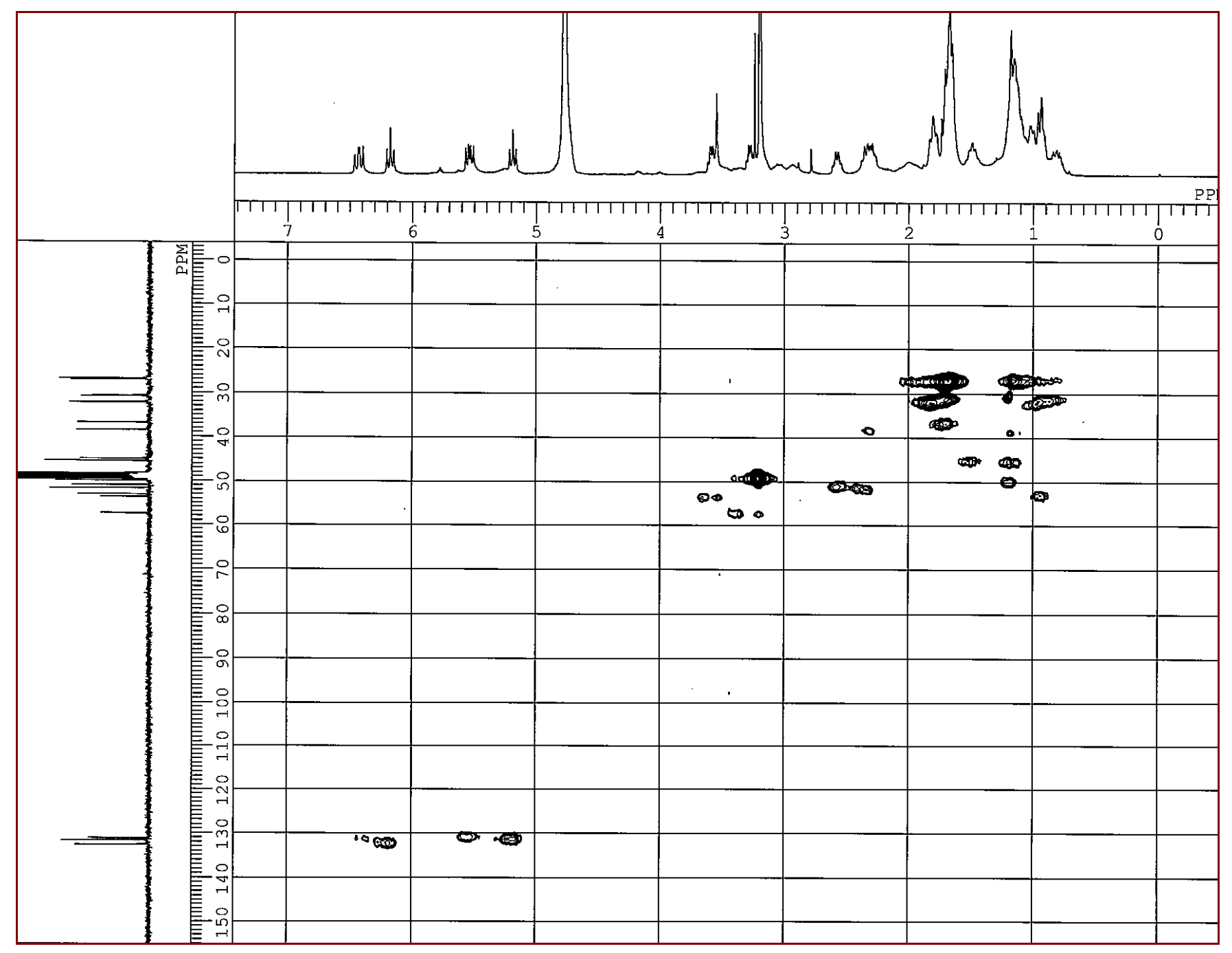

Figure S19. HMQC spectrum of $\mathbf{3}$ in $\mathrm{CD}_{3} \mathrm{OD}$. 


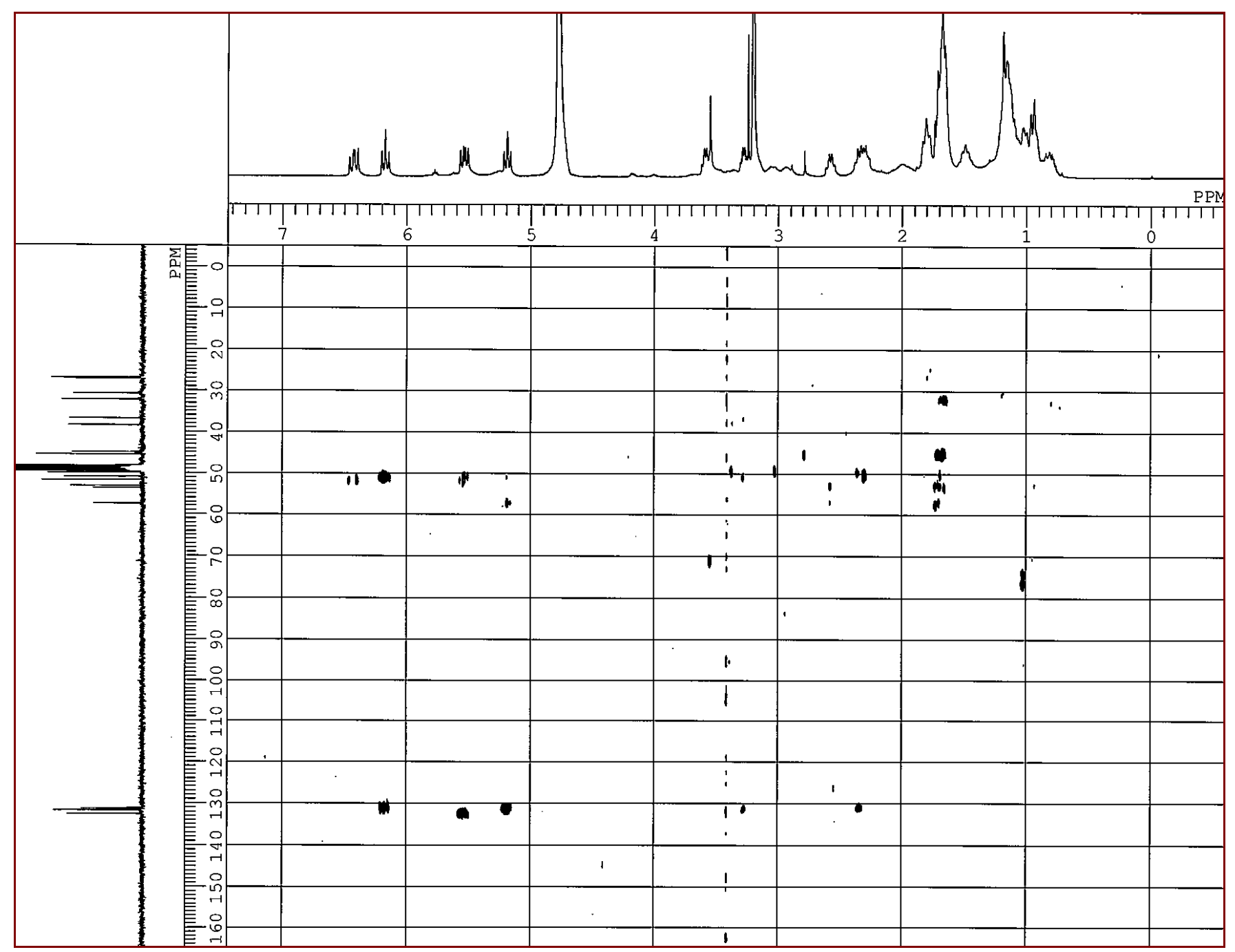

Figure S20. $\mathrm{HMBC}$ spectrum of $\mathbf{3}$ in $\mathrm{CD}_{3} \mathrm{OD}$. 


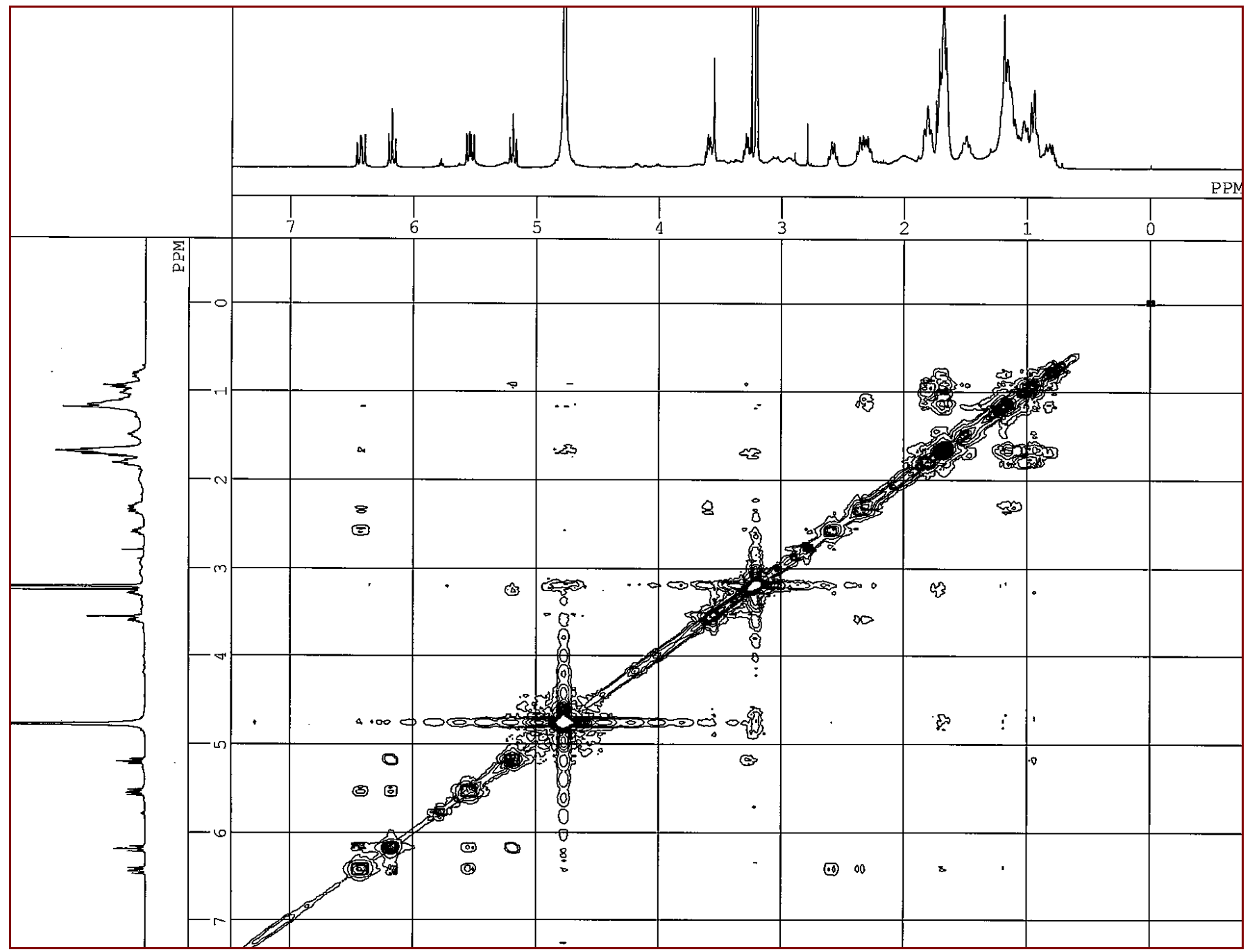

Figure S21. NOESY spectrum of $\mathbf{3}$ in $\mathrm{CD}_{3} \mathrm{OD}$. 


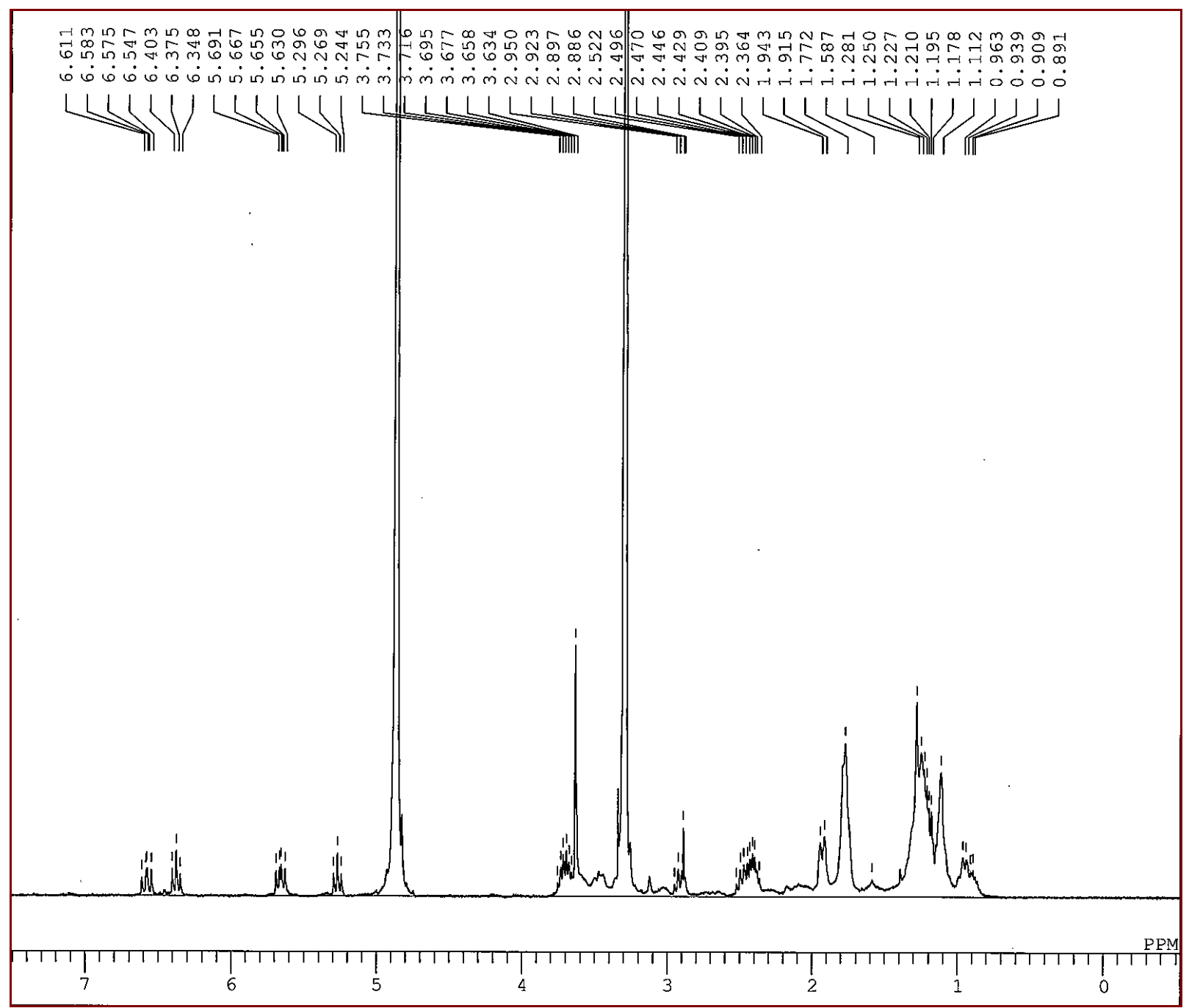

Figure S22. ${ }^{1} \mathrm{H}$ NMR spectrum of $\mathbf{4}$ in $\mathrm{CD}_{3} \mathrm{OD}$. 


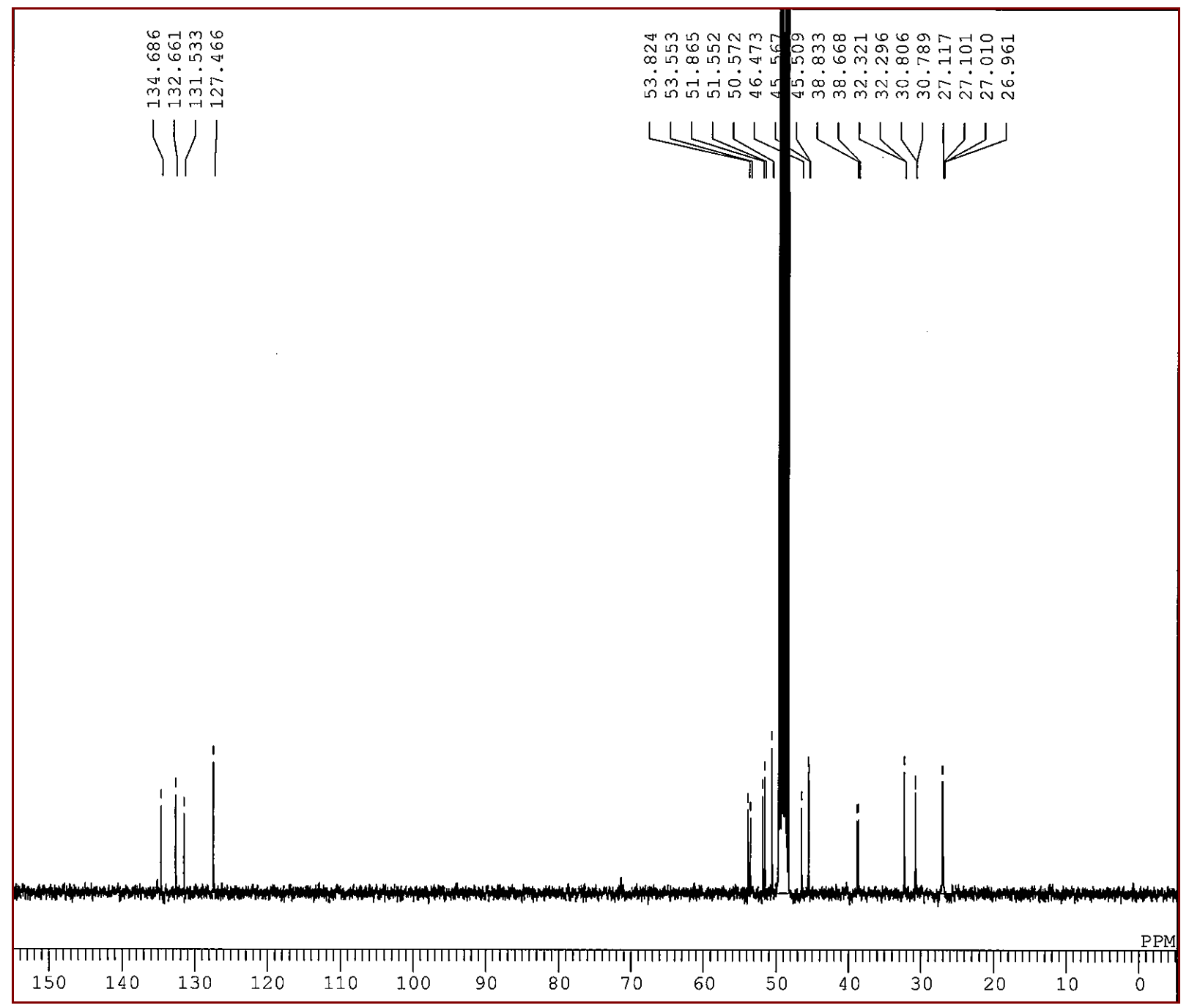

Figure S23. ${ }^{13} \mathrm{C}$ NMR spectrum of $\mathbf{4}$ in $\mathrm{CD}_{3} \mathrm{OD}$. 


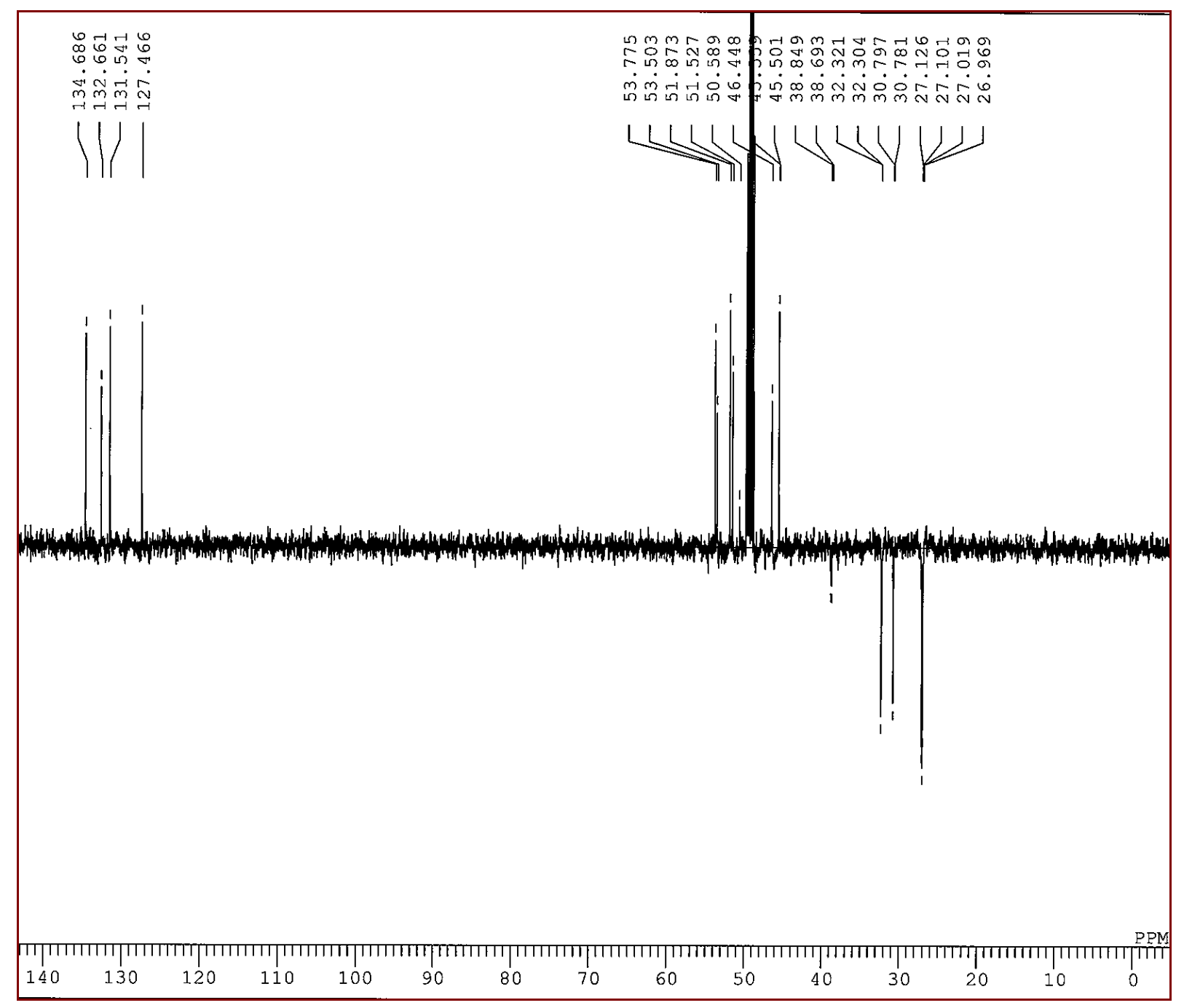

Figure S24. DEPT spectrum of $\mathbf{4}$ in $\mathrm{CD}_{3} \mathrm{OD}$. 


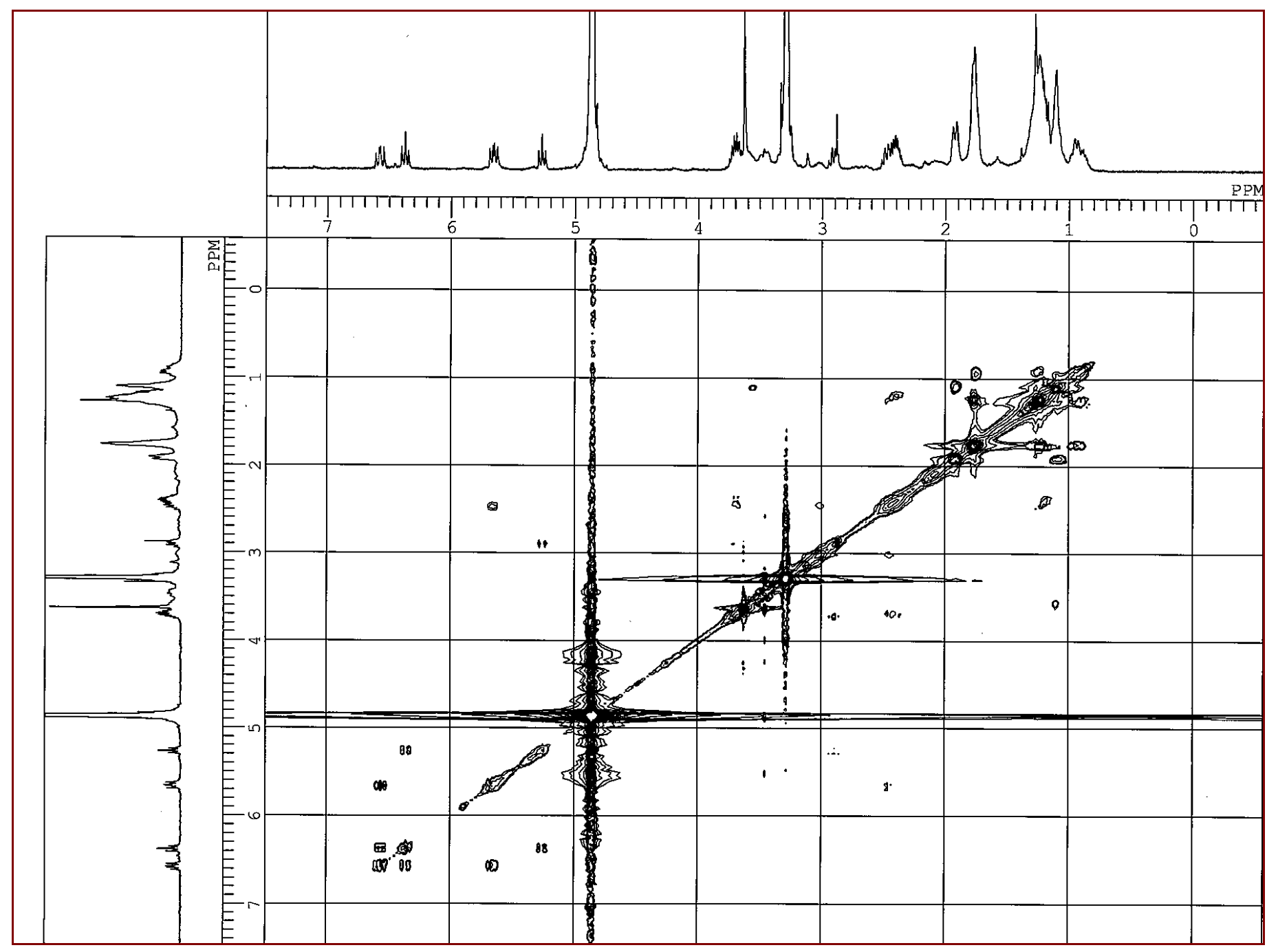

Figure S25. ${ }^{1} \mathrm{H}-{ }^{1} \mathrm{H}$ COSY spectrum of 4 in $\mathrm{CD}_{3} \mathrm{OD}$. 


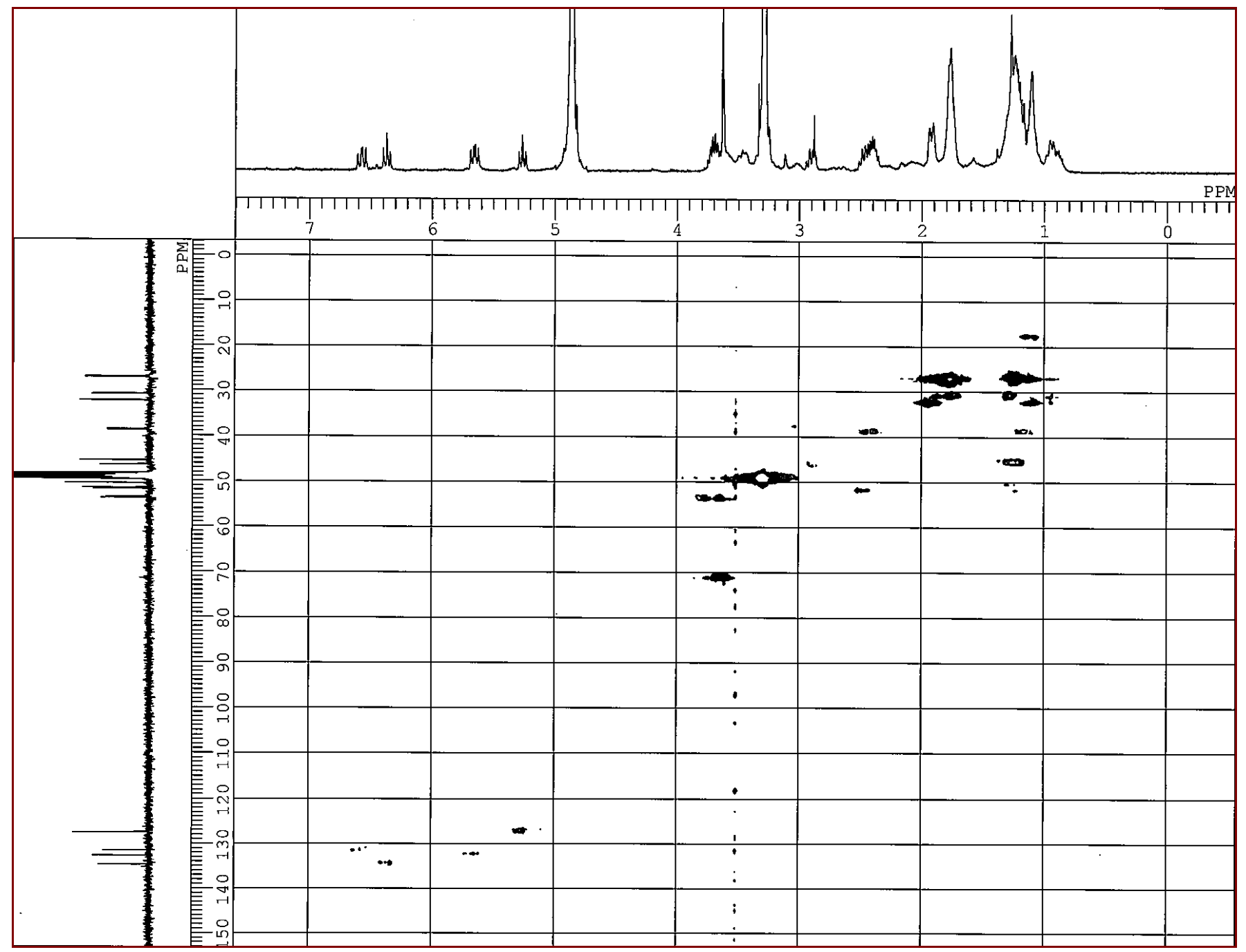

Figure S26. HMQC spectrum of $\mathbf{4}$ in $\mathrm{CD}_{3} \mathrm{OD}$. 


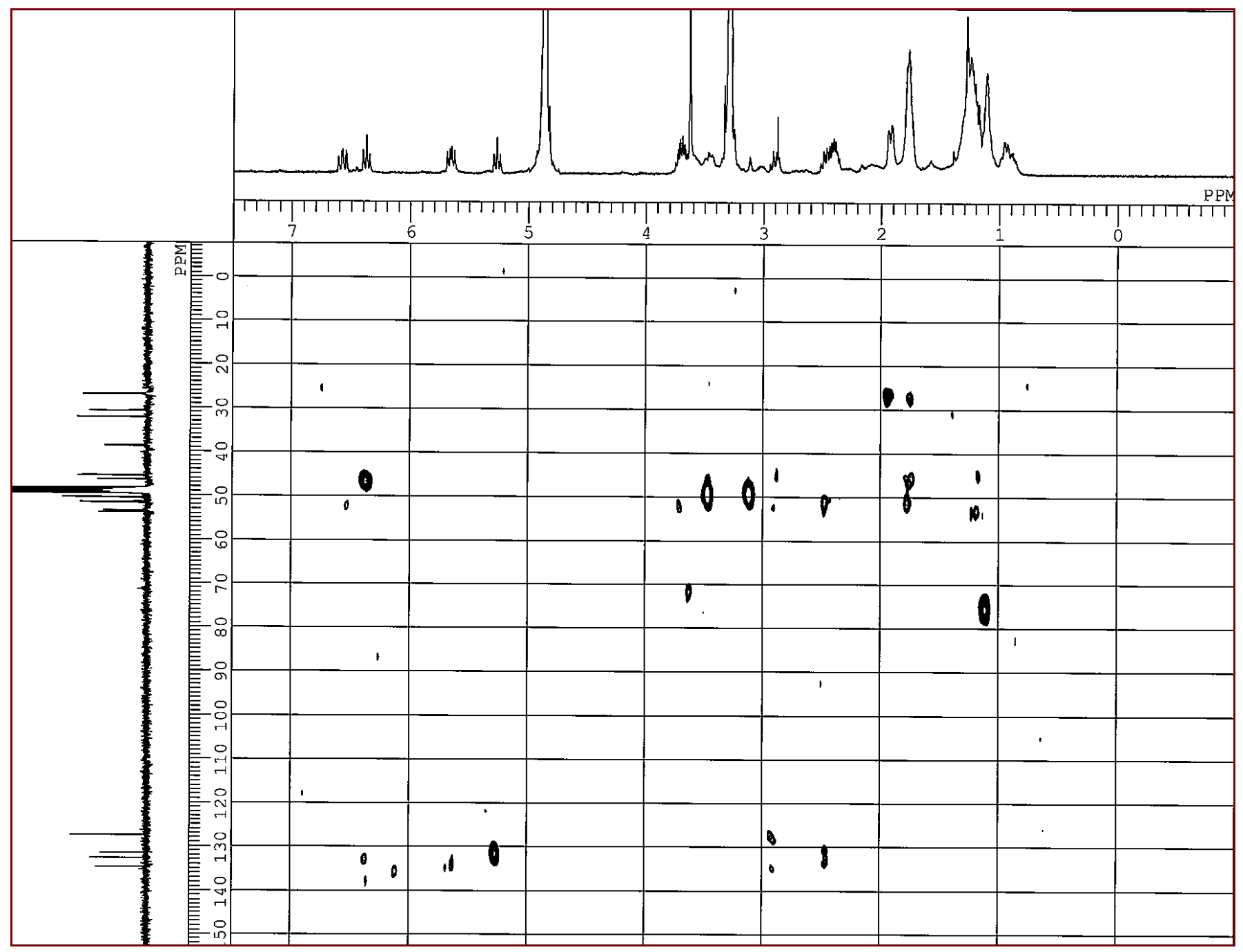

Figure S27. $\mathrm{HMBC}$ spectrum of $\mathbf{4}$ in $\mathrm{CD}_{3} \mathrm{OD}$. 


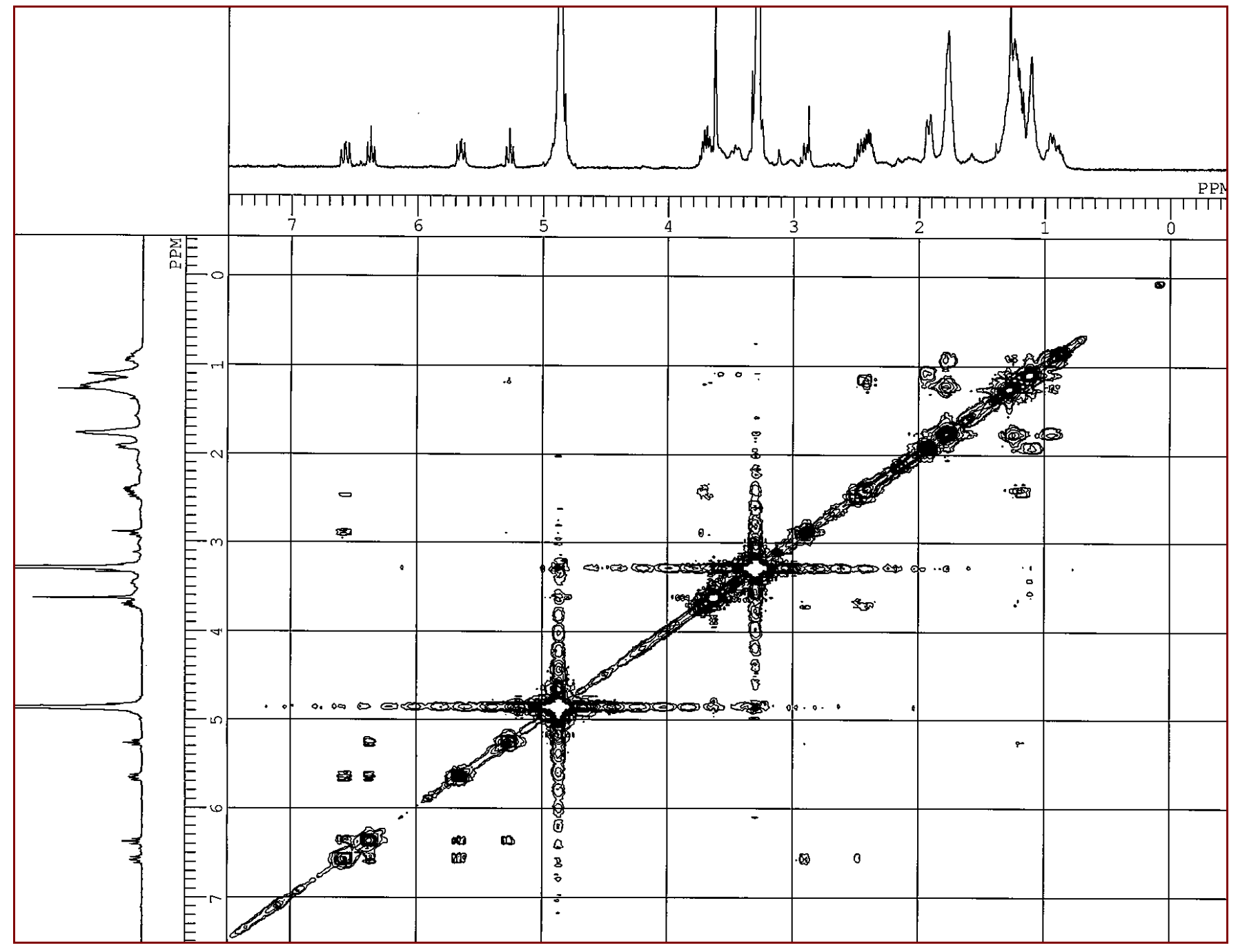

Figure S28. NOESY spectrum of $\mathbf{4}$ in $\mathrm{CD}_{3} \mathrm{OD}$. 


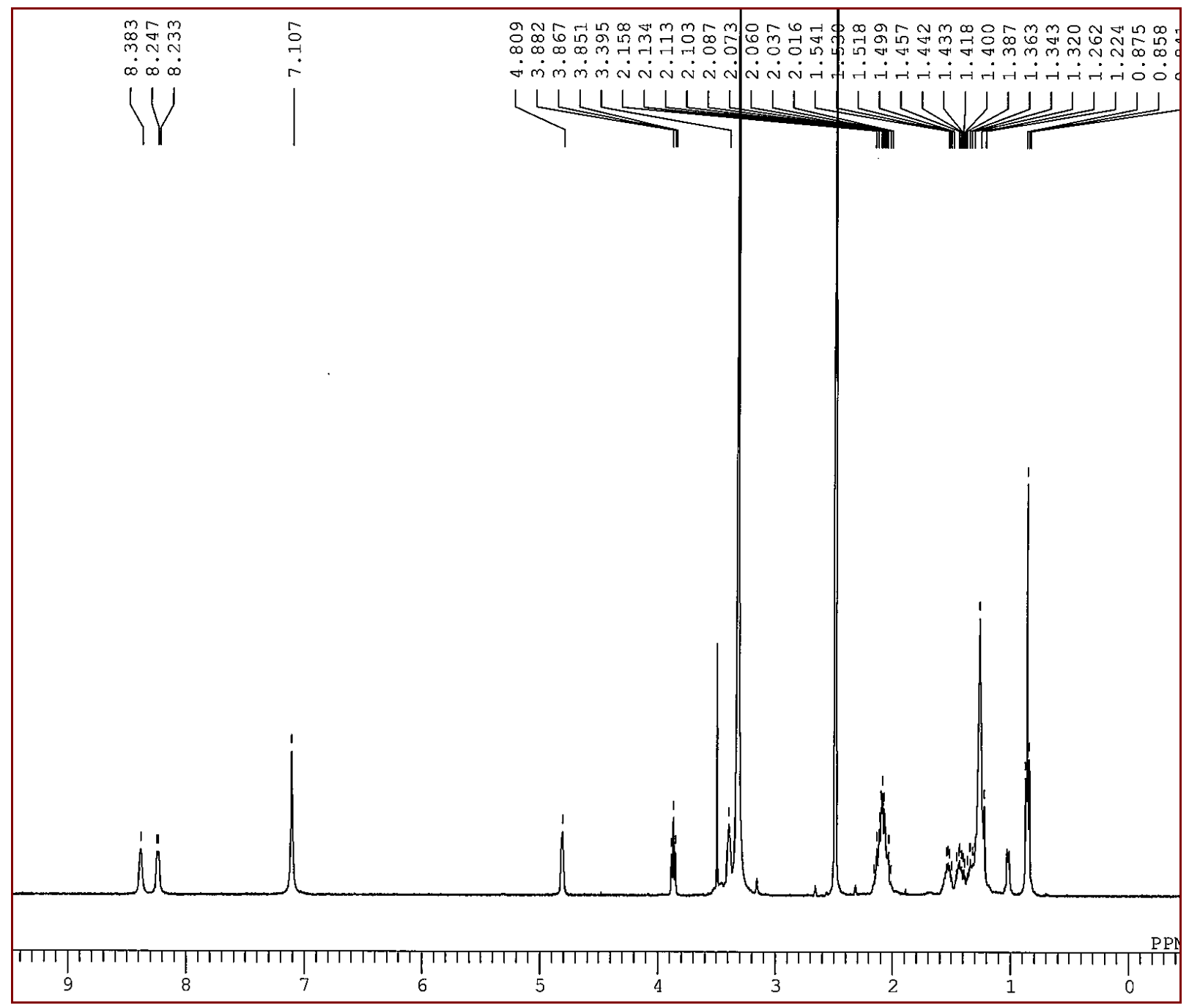

Figure S29. ${ }^{1} \mathrm{H}$ NMR spectrum of 7 in DMSO- $d_{6}$. 


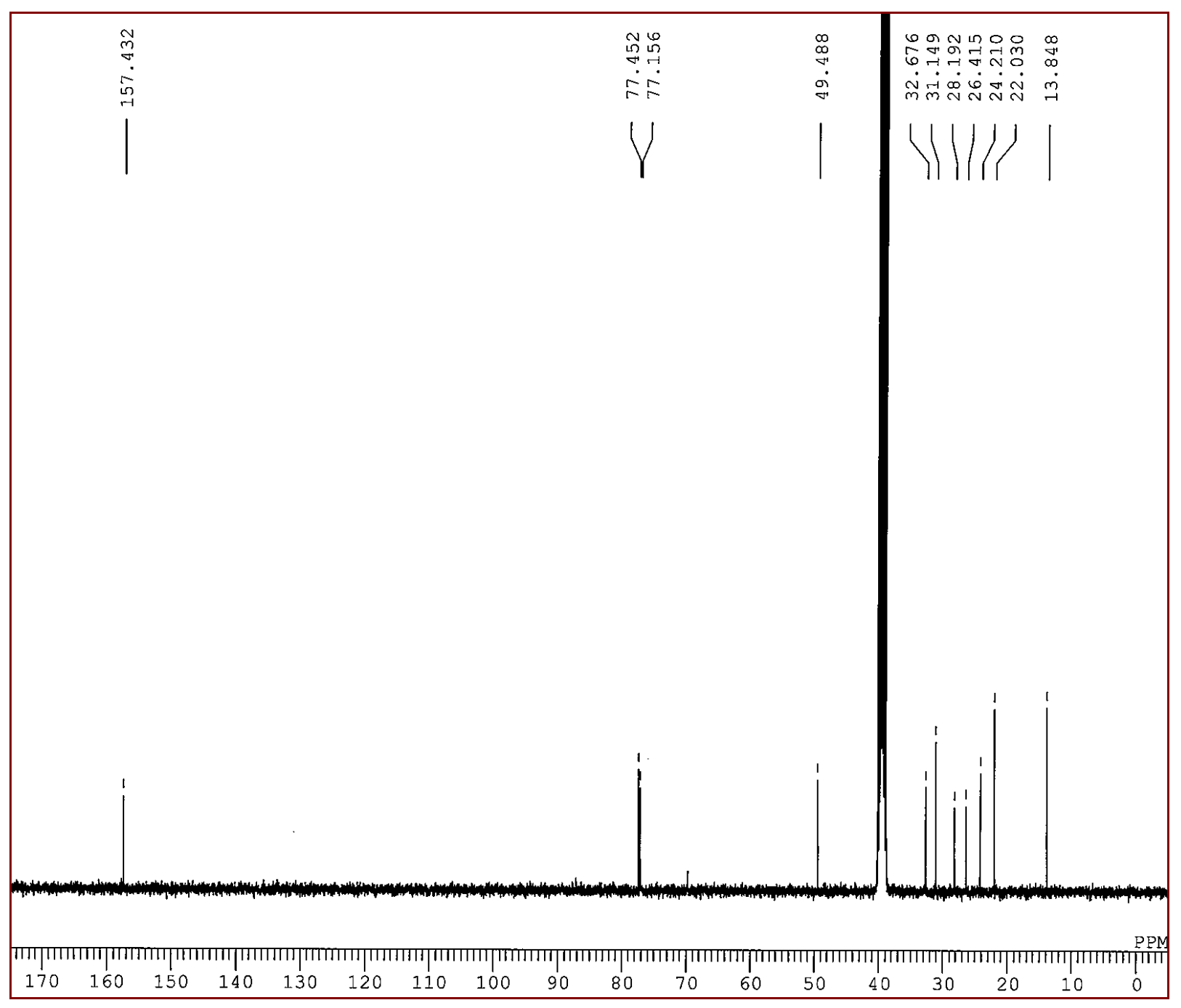

Figure S30. ${ }^{13} \mathrm{C}$ NMR spectrum of 7 in DMSO- $d_{6}$. 


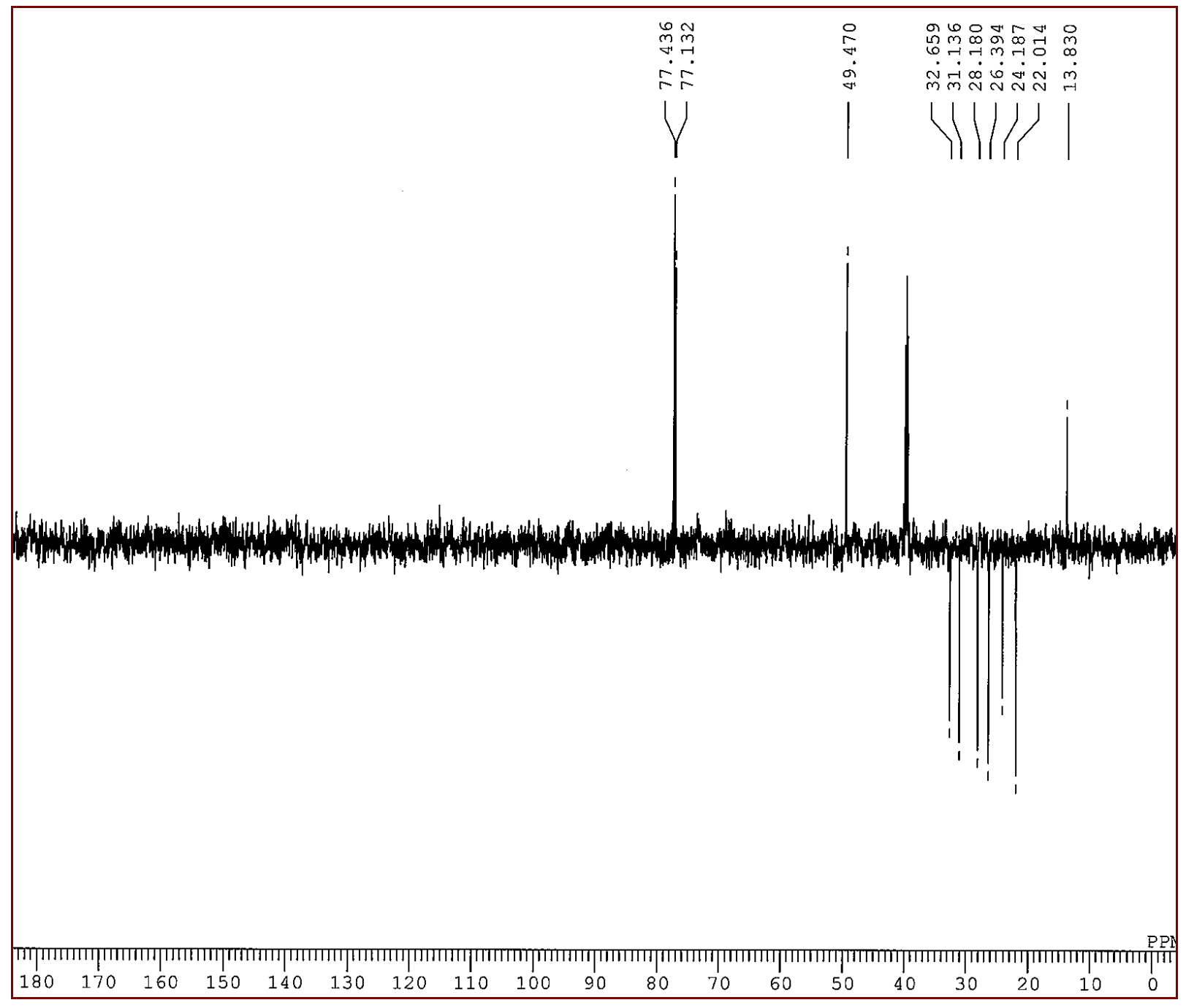

Figure S31. DEPT spectrum of 7 in DMSO- $d_{6}$. 


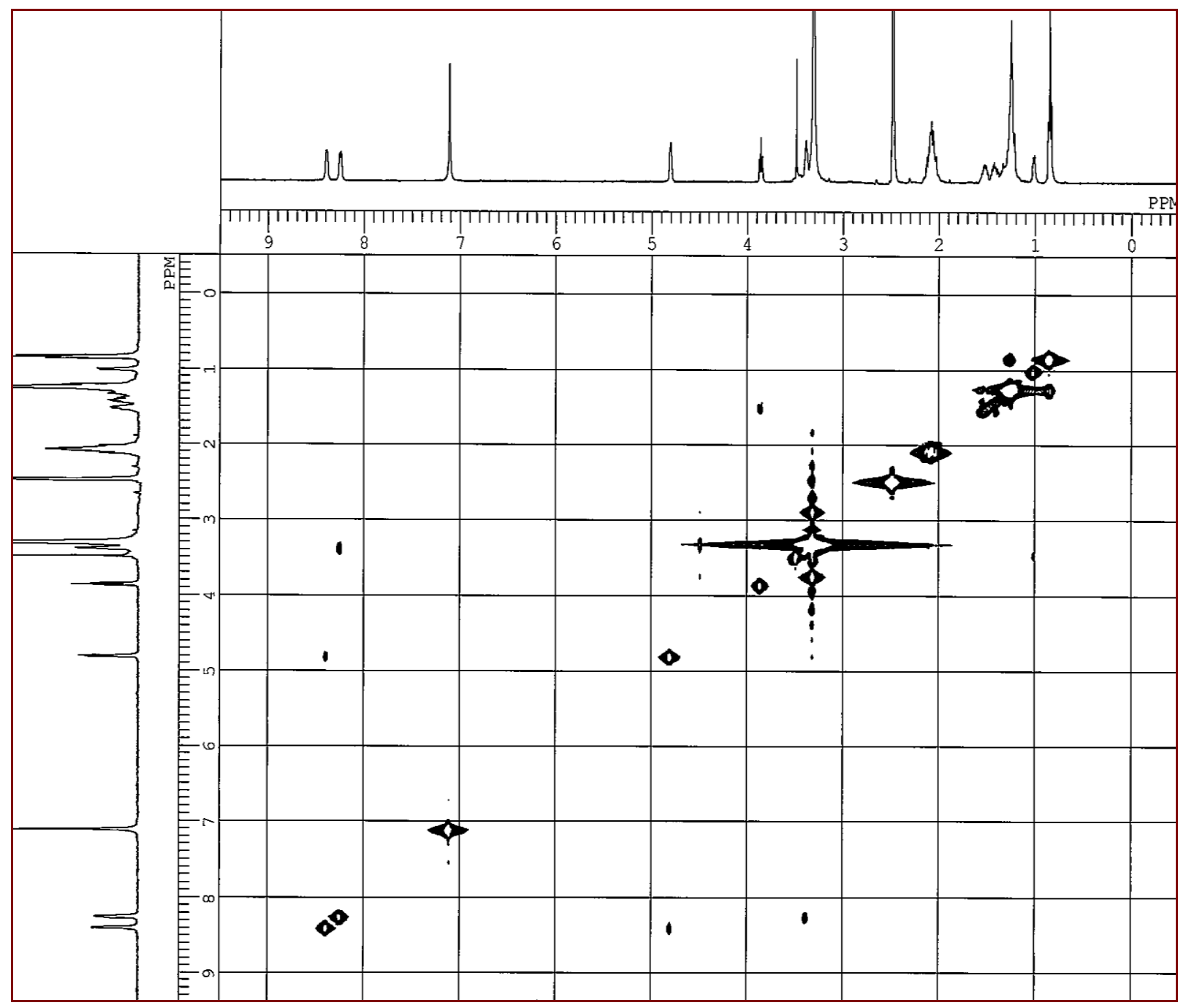

Figure S32. ${ }^{1} \mathrm{H}-{ }^{1} \mathrm{H}$ COSY spectrum of 7 in DMSO- $d_{6}$. 


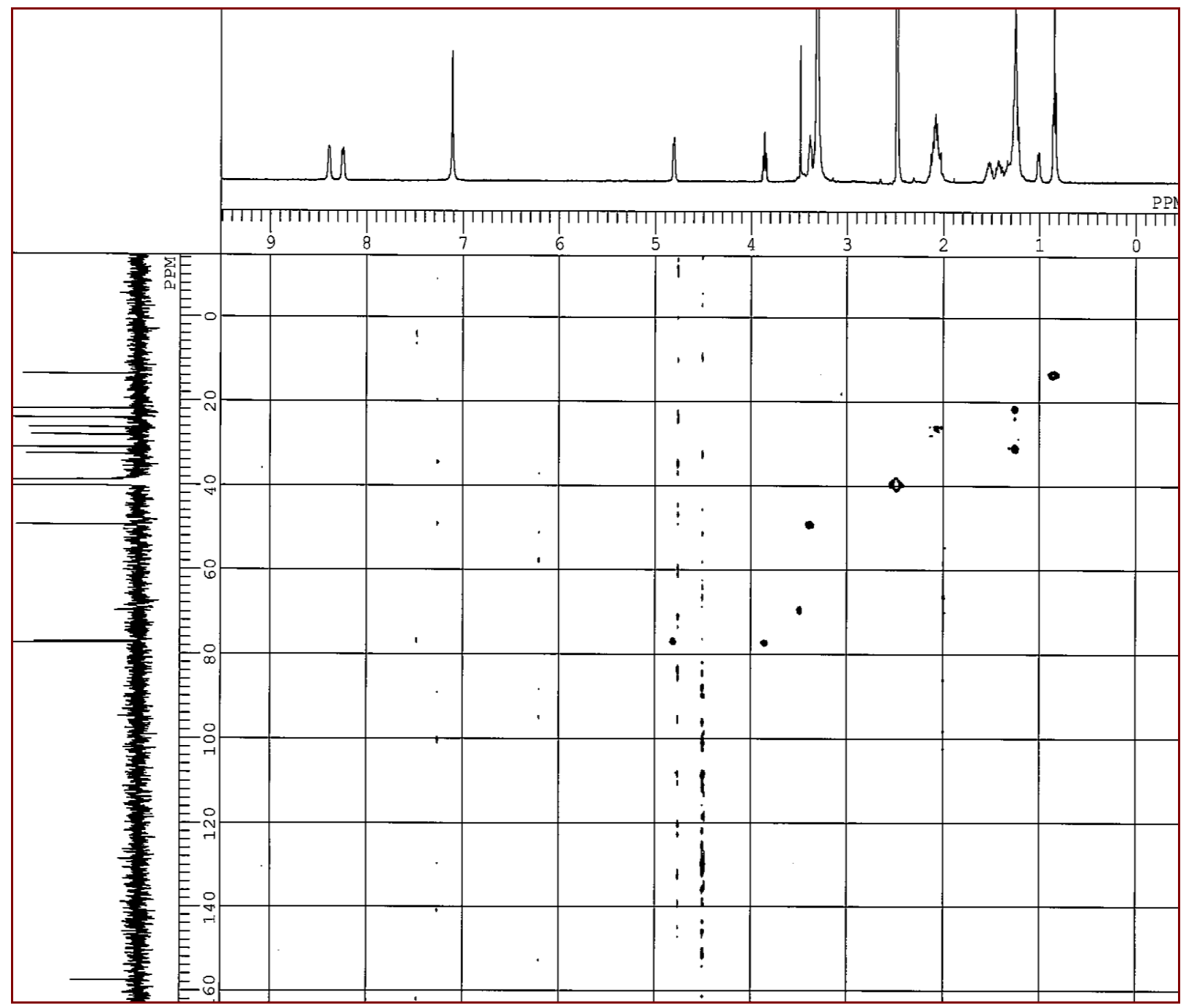

Figure S33. HMQC spectrum of 7 in DMSO- $d_{6}$. 


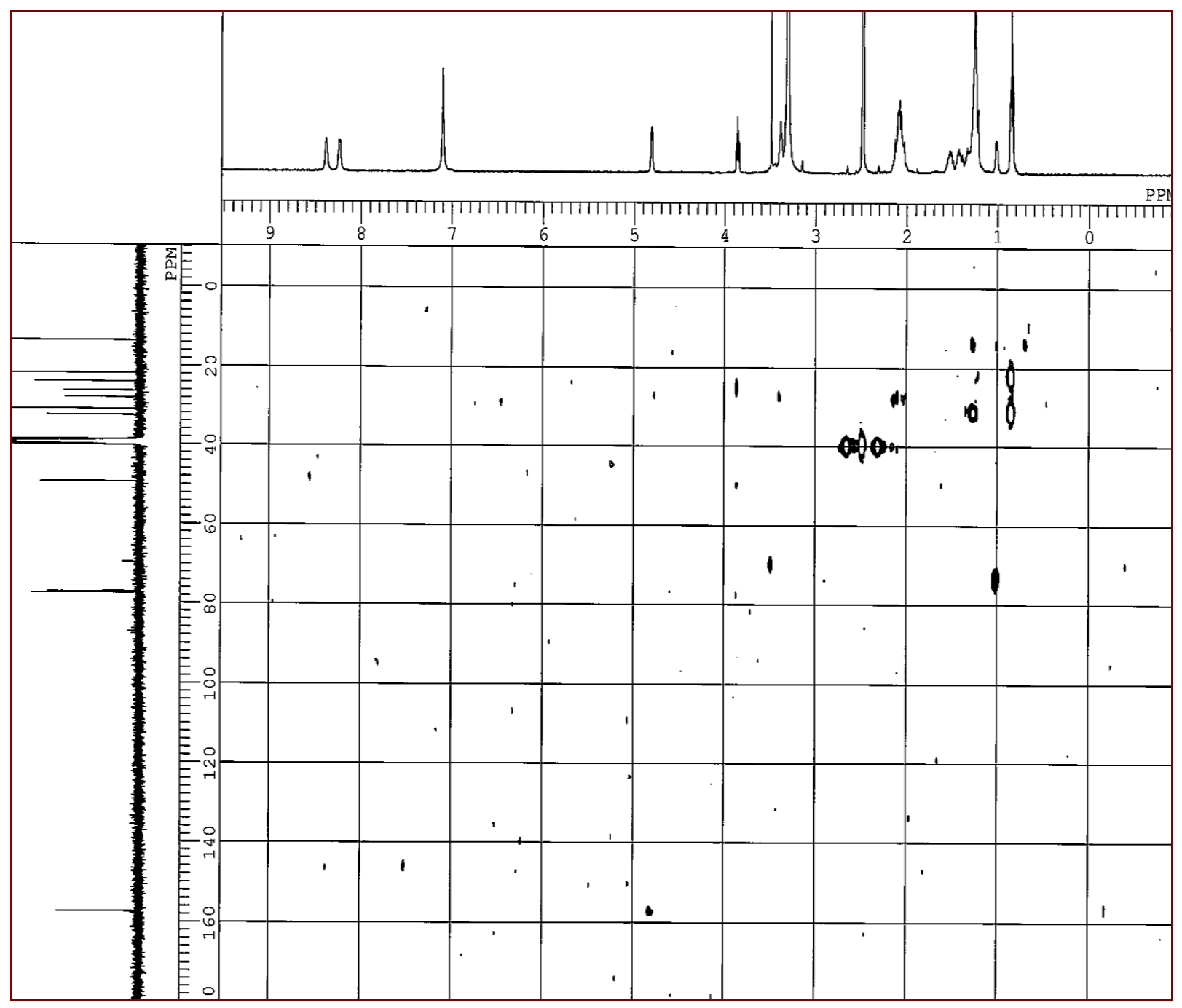

Figure S34. HMBC spectrum of 7 in DMSO- $d_{6}$. 


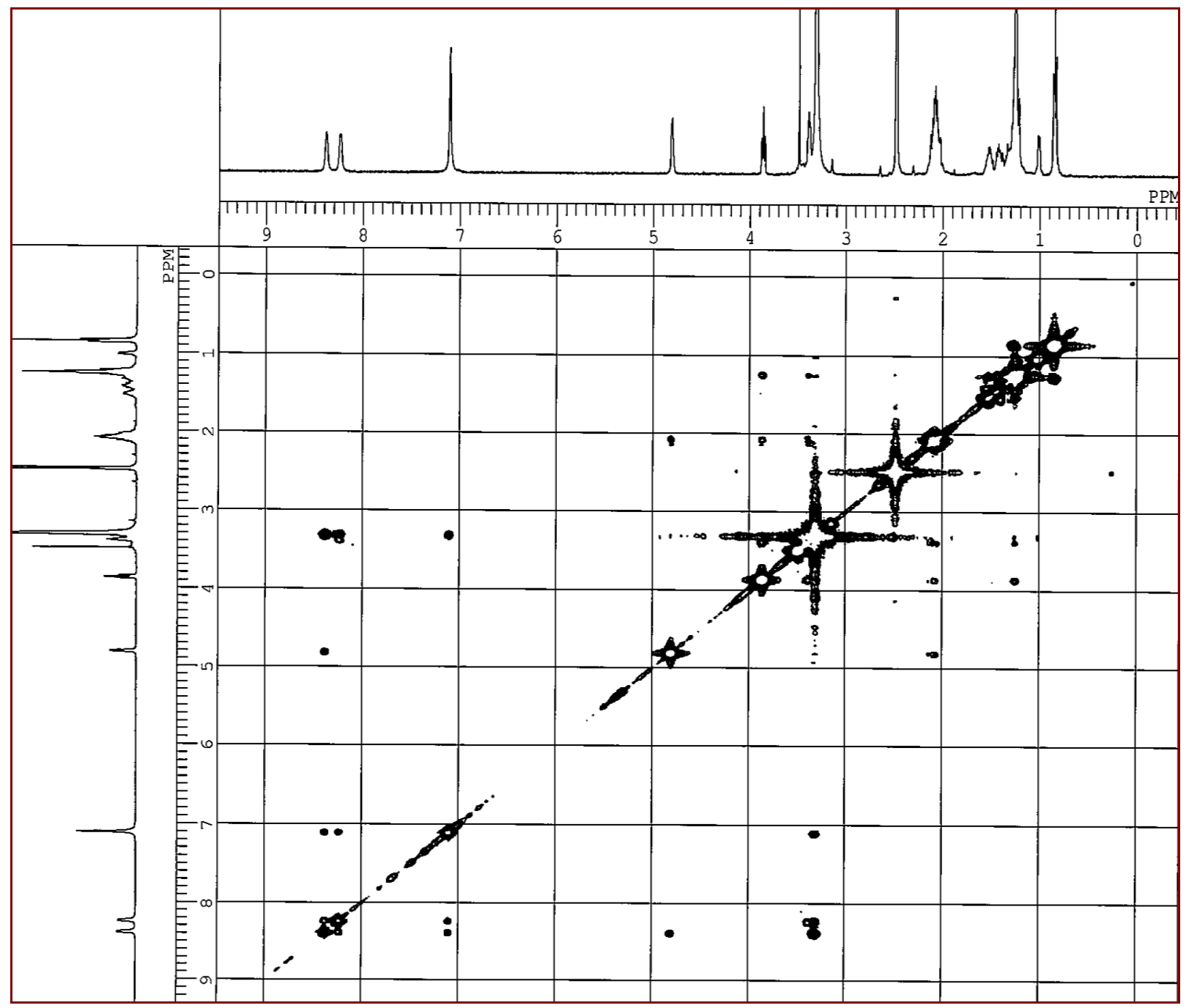

Figure S35. NOESY spectrum of 7 in DMSO- $d_{6}$. 